\title{
Trends in emissions and concentrations of air pollutants in the lower troposphere in the Baltimore/Washington airshed from 1997 to 2011
}

\author{
H. He ${ }^{1,2}$, J. W. Stehrr ${ }^{1}$, J. C. Hains ${ }^{3}$, D. J. Krask ${ }^{3}$, B. G. Doddridge ${ }^{4}$, K. Y. Vinnikov ${ }^{1}$, T. P. Canty ${ }^{1}$, K. M. Hosley ${ }^{1}$, \\ R. J. Salawitch ${ }^{1,2,5}$, H. M. Worden ${ }^{6}$, and R. R. Dickerson ${ }^{1,2,5}$ \\ ${ }^{1}$ Department of Atmospheric and Oceanic Science, University of Maryland, College Park, MD 20742, USA \\ ${ }^{2}$ Earth System Science Interdisciplinary Center, University of Maryland, College Park, MD 20740, USA \\ ${ }^{3}$ Maryland Department of the Environment, Baltimore, MD 21230, USA \\ ${ }^{4}$ Chemistry and Dynamics Branch, NASA Langley Research Center, Hampton, VA 23681, USA \\ ${ }^{5}$ Department of Chemistry and Biochemistry, University of Maryland, College Park, MD 20742, USA \\ ${ }^{6}$ National Center for Atmospheric Research, Boulder, CO 80305, USA
}

Correspondence to: H. He (hhe@atmos.umd.edu)

Received: 5 January 2013 - Published in Atmos. Chem. Phys. Discuss.: 4 February 2013

Revised: 10 July 2013 - Accepted: 10 July 2013 - Published: 15 August 2013

\begin{abstract}
Trends in the composition of the lower atmosphere (0-1500 $\mathrm{m}$ altitude) and surface air quality over the Baltimore/Washington area and surrounding states were investigated for the period from 1997 to 2011. We examined emissions of ozone precursors from monitors and inventories as well as ambient ground-level and aircraft measurements to characterize trends in air pollution. The US EPA Continuous Emissions Monitoring System (CEMS) program reported substantial decreases in emission of summertime nitrogen oxides $\left(\mathrm{NO}_{\mathrm{x}}\right)$ from power plants, up to $\sim 80 \%$ in the mid-Atlantic States. These large reductions in emission of $\mathrm{NO}_{\mathrm{x}}$ are reflected in a sharp decrease of groundlevel concentrations of $\mathrm{NO}_{\mathrm{x}}$ starting around 2003. The decreasing trend of tropospheric column $\mathrm{CO}$ observed by aircraft is $\sim 0.8$ Dobson unit (DU) per year, corresponding to $\sim 35 \mathrm{ppbv} \mathrm{yr}^{-1}$ in the lower troposphere (the surface to $1500 \mathrm{~m}$ above ground level). Satellite observations of longterm, near-surface $\mathrm{CO}$ show a $\sim 40 \%$ decrease over western Maryland between 2000 and 2011; the same magnitude is indicated by aircraft measurements above these regions upwind of the Baltimore/Washington airshed. With decreasing emissions of ozone precursors, the ground-level ozone in the Baltimore/Washington area shows a $0.6 \mathrm{ppbv} \mathrm{yr}^{-1} \mathrm{de}-$ crease in the past $15 \mathrm{yr}$. Since photochemical production of ozone is substantially influenced by ambient temperature, we introduce the climate penalty factor (CPF) into the trend analysis of long-term aircraft measurements. After compen-
\end{abstract}

sating for inter-annual variations in temperature, historical aircraft measurements indicate that the daily net production of tropospheric ozone over the Baltimore/Washington area decreased from $\sim 20 \mathrm{ppbv} \mathrm{day}^{-1}$ in the late $1990 \mathrm{~s}$ to $\sim 7 \mathrm{ppbv} \mathrm{day}^{-1}$ in the early 2010 s during ozone season. A decrease in the long-term column ozone is observed as $\sim 0.2$ $\mathrm{DU} \mathrm{yr}^{-1}$ in the lowest $1500 \mathrm{~m}$, corresponding to an improvement of $\sim 1.3 \mathrm{ppbv} \mathrm{yr}^{-1}$. Our aircraft measurements were conducted on days when severe ozone pollution was forecasted, and these results represent the decreasing trend in high ozone events over the past $15 \mathrm{yr}$. Back trajectory cluster analysis demonstrates that emissions of air pollutants from Ohio and Pennsylvania through Maryland influence the column abundances of downwind ozone in the lower atmosphere. The trends in air pollutants reveal the success of regulations implemented over the past decades and the importance of region-wide emission controls in the eastern United States.

\section{Introduction}

Ozone controls much of the chemistry in the lower atmosphere, such as hydroxyl radical $(\mathrm{OH})$ production and the lifetimes of atmospheric species including methane $\left(\mathrm{CH}_{4}\right)$, carbon monoxide $(\mathrm{CO})$, and volatile organic compounds (VOCs) (Levy, 1971; Logan et al., 1981; 
Seinfeld and Pandis, 2006). Tropospheric ozone is a good absorber of thermal radiation, acting as the third most important anthropogenic contributor to radiative forcing of climate (Fishman et al., 1979a; Ramanathan and Dickinson, 1979; IPCC, 2007). High concentrations of ground-level ozone also threaten human health (WHO, 2003; Anderson, 2009; Jerrett et al., 2009) and cause damage to ecosystems (Adams et al., 1989; Chameides et al., 1999; Ashmore, 2005). Thus, ozone is one of the six criteria pollutants regulated by the US Environmental Protection Agency (EPA) through National Ambient Air Quality Standards (NAAQS).

As a secondary air pollutant, the majority of ozone in the lower troposphere is produced by photochemical reactions involving $\mathrm{CO}$ and VOCs in the presence of nitrogen oxides $\left(\mathrm{NO}_{\mathrm{x}}\right)$ (Crutzen, 1974; Fishman et al., 1979b; EPA, 2006), while troposphere-stratosphere exchange of air contributes substantial amounts of ozone to the upper troposphere (Levy et al., 1985; Holton et al., 1995; Wild et al., 2003; Stevenson et al., 2006). In the US, ozone pollution drew public attention starting with the "Los Angeles smog" events in the 1950s (Haagensmit, 1952; Haagensmit and Fox, 1956). Emissions of ozone precursors, mainly $\mathrm{NO}_{\mathrm{x}}, \mathrm{CO}$, and VOCs from anthropogenic sources, have decreased significantly under regulation, resulting in lower ground-level ozone (Cooper et al., 2012). Long-term records of tropospheric ozone in the US have been investigated through ground-level observations (Oltmans et al., 2006; Jaffe and Ray, 2007; Lefohn et al., 2008, 2010; Oltmans et al., 2013), however trends of ozone are not monotonic (Cooper et al., 2012; Oltmans et al., 2013). Analysis of these long-term ozone measurements can also shed light on the change of "baseline" ozone in order to estimate the flux of air pollutants entering and exiting North America, relevant to regulation of ambient air quality (Oltmans et al., 2008; Parrish et al., 2009; Chan and Vet, 2010; Cooper et al., 2010; Lin et al., 2012).

In the mid-Atlantic States, ozone is a major air pollutant during summer (EPA, 2012a). The Baltimore/Washington area has failed to meet mandated attainment deadlines (EPA, 2012b); despite tremendous improvements in local air quality over the past several decades, a significant number of exceedances of the current 75 parts per billion by volume (ppbv), $8 \mathrm{~h}$ surface ozone standard, were experienced. The design value of daily maximum $8 \mathrm{~h}$ ozone for Edgewood, MD (generally downwind of Baltimore), was $92 \mathrm{ppbv}$ in 2011 (http://www.epa.gov/airtrends/values.html).

The Regional Atmospheric Measurement Modeling and Prediction Program (RAMMPP, http://www.atmos.umd.edu/ $\sim$ RAMMPP) led by the University of Maryland was created to conduct state-of-the-art scientific research pertaining to surface ozone, through in situ measurements, air quality forecasting, mesoscale dynamics modeling, and chemical transport modeling. As a key component of RAMMPP, aircraft measurements of air pollutants have been conducted during the ozone season (May to September) over the past $15 \mathrm{yr}$ (Taubman et al., 2006; Hains et al., 2008). At present, the
RAMMPP aircraft has the capability to measure $\mathrm{CO}, \mathrm{O}_{3}$, sulfur dioxide $\left(\mathrm{SO}_{2}\right)$, nitrogen dioxide $\left(\mathrm{NO}_{2}\right)$, aerosol absorption, aerosol scattering, particle counts, aerosol size distribution, as well as meteorological variables.

The RAMMPP aircraft program started with measurements of tropospheric $\mathrm{O}_{3}$ and $\mathrm{CO}$ in 1997, providing a $15 \mathrm{yr}$ record for investigating summertime air quality trends in the Baltimore/Washington airshed. Many air quality studies focus on the trends in ground-level ozone (Fiore et al., 1998; Jaffe and Ray, 2007; Lefohn et al., 2008, 2010; Cooper et al., 2012). In the free troposphere (FT), ozone and its precursors have longer lifetimes and can be transported farther downwind than constituents near the surface (Luke et al., 1992; Jaffe, 2011; Neuman et al., 2012). The Baltimore/Washington nonattainment area is downwind of the Ohio River valley, where a large number of power plants are located, and upwind of other nonattainment areas such as Philadelphia, New Jersey and New York City. Previous studies using ozonesonde measurements have revealed the importance of regional transport and Chesapeake Bay meteorological effects on ozone pollution in the Baltimore/Washington area (Yorks et al., 2009; Martins et al., 2013; Stauffer et al., 2013). Distinguishing local ozone production from regional transport is critical for effective policy and control measures.

We quantify trends in summertime air pollution over the past $15 \mathrm{yr}$ using measurements of tropospheric ozone and its precursors $\left(\mathrm{CO}\right.$ and $\left.\mathrm{NO}_{\mathrm{x}}\right)$ in the mid-Atlantic region and upwind states, as well as national and regional emissions data. Section 2 presents the data sets and methods. In Sect. 3, we discuss the trends in emissions near the Baltimore/Washington airshed, and the trends in tropospheric $\mathrm{O}_{3}$ and $\mathrm{CO}$ observed by the RAMMPP aircraft and EPA Air Quality System (AQS) network. A case study on regional transport is conducted using a back trajectory clustering technique to reveal the relationship between upwind anthropogenic emissions and downwind air quality. Finally, we discuss the importance of emission regulation for improving ozone pollution in the nonattainment Baltimore/Washington airshed, as well as implications for future control measures.

\section{Data and methods}

For our study of ozone pollution in the Baltimore/Washington airshed, two emissions data sets were used: the EPA National Emissions Inventory (NEI) and the CEMS data for states of Maryland (MD), Virginia (VA), West Virginia (WV), Pennsylvania (PA) and Ohio $(\mathrm{OH})$ (the mid-Atlantic and one upwind state, hereafter named the research domain). The NEI emissions inventory, a comprehensive estimate of emissions for both criteria and hazardous air pollutants from all sources on the county scale, is prepared every three years, based on emission surveys and specialized emission modeling tools (e.g., http://www.epa.gov). In the NEI, emissions are grouped 
into five categories: point, nonpoint, onroad, nonroad, and event (details given in Table S1 of the Supplement). Here, detailed NEI data (2002, 2005, and 2008) and summaries of annual national data (available at: http://www.epa.gov) were utilized to study the trends of ozone precursor emissions from point and mobile sources. The NEI only provides annual emission estimates. To investigate daily changes of emissions, we examined CEMS data from continuous monitoring of point sources; i.e., major power plants and industries, covered by the EPA Clean Air Markets Division (data available at: http://ampd.epa.gov/ampd/). The CEMS data include $\mathrm{NO}_{\mathrm{x}}, \mathrm{SO}_{2}$ and carbon dioxide $\left(\mathrm{CO}_{2}\right)$ emissions, with temporal resolution as fine as hourly from individual point sources. Previous studies indicate that $\mathrm{NO}_{\mathrm{x}}$ emissions from point sources substantially influence surface ozone (Frost et al., 2006; Kim et al., 2006; Hains et al., 2008). Here, daily CEMS data for $\mathrm{NO}_{\mathrm{x}}$ emissions from sources within the research domain from 1997 to 2011 were used.

Measurements of $\mathrm{NO}_{\mathrm{x}}, \mathrm{CO}$ and $\mathrm{O}_{3}$ from ground stations throughout the Baltimore/Washington area archived on the EPA AQS website (http://www.epa.gov/ttn/airs/ airsaqs/detaildata/downloadaqsdata.htm) were used to quantify trends in surface air pollution. $\mathrm{NO}_{\mathrm{x}}$ measurements provided by the EPA are achieved through conversion of $\mathrm{NO}_{2}$ to NO using a hot molybdenum catalyst, followed by the chemiluminescence reaction of $\mathrm{NO}$ with $\mathrm{O}_{3}$. Interferences from other oxidized reactive nitrogen species such as peroxyacyl nitrates (PAN) and alkyl nitrates are almost certain (Fehsenfeld et al., 1987; Dunlea et al., 2007). Correcting the EPA measurements of $\mathrm{NO}_{\mathrm{x}}$ for potential interferences is beyond the scope of this study. Any interfering compounds originate from chemical reactions involving $\mathrm{NO}_{\mathrm{x}}$, so the EPA $\mathrm{NO}_{\mathrm{x}}$ record is consistent over the course of this study and almost certainly provides a surrogate for trends in actual ambient $\mathrm{NO}_{\mathrm{x}}$.

Since CO is emitted mainly by automobiles and incomplete combustion such as biomass burning, anthropogenic emissions of $\mathrm{CO}$ are not monitored as are $\mathrm{NO}_{\mathrm{x}}$ and $\mathrm{SO}_{2}$ emissions from point sources in the CEMS program. The EPA estimates national emissions of $\mathrm{CO}$ using models such as the Motor Vehicle Emissions Simulator (MOVES). MOPITT (Measurements of Pollution In the Troposphere) on Terra (Deeter et al., 2003), launched in 1999, has together with measurements from numerous other satellite instruments proven useful for tracking the long-term trend of tropospheric CO on regional scales (Worden et al., 2013). A $\sim 15 \%$ decrease was reported for column of CO over the eastern US between 2000 and 2011. Here we used the MOPITT version 5 level 3 monthly products that exploit both near and thermal infrared radiances (MOP03JM.005, https: //eosweb.larc.nasa.gov/project/mopitt/mopitt_table). We selected the $\mathrm{CO}$ values from the surface to $900 \mathrm{hPa}$ (Deeter et al., 2012) to compare with RAMMPP aircraft measurements of $\mathrm{CO}$ in the lower troposphere. We note that although MOPITT multispectral retrievals have highly variable sensitiv- ity to near-surface $\mathrm{CO}$ over different surface types, retrievals over the mid-Atlantic region considered in this study showed consistently good sensitivity to near-surface $\mathrm{CO}$ (Worden et al., 2010). For MOPITT data used in this analysis, the sensitivity to CO typically peaks in the surface layer from 1000 to $900 \mathrm{hPa}$ and falls off exponentially with a scale height of $\sim 1 \mathrm{~km}$, making them suitable for comparison with our aircraft measurements.

RAMMPP aircraft observations of tropospheric $\mathrm{O}_{3}$ and CO date back to 1997 , providing a $15 \mathrm{yr}$ record of summertime air quality. The sampling platform for the early 2000s was discussed extensively in previous studies (Taubman et al., 2006; Hains et al., 2008); details of the current sampling platform are listed in Table S2 of the Supplement. Here, a brief summary of $\mathrm{O}_{3}$ and $\mathrm{CO}$ measurements is provided. Ozone is measured using a commercially available analyzer (Model 49/49C, Thermo Environmental Instruments, TEI, Franklin Massachusetts), based on the absorption of ultraviolet radiation. The analyzer is routinely serviced and calibrated with an in-house primary ozone calibrator (TEI Model 49PS) using zero-grade air. The instrument has been compared to the National Institute of Standard and Technology (NIST) standard, and the precision can reach $1 \mathrm{ppbv}$ for $10 \mathrm{~s}$ average data (Taubman et al., 2006). Observations of ambient CO are conducted using a modified commercially available nondispersive infrared gas filter correlation analyzer (TEI Model 48) with enhanced precision of about $30 \mathrm{ppbv}$ for 1 min moving average of $10 \mathrm{~s}$ data (Dickerson and Delany, 1988). The detector is regularly calibrated with a NIST traceable CO gas standard (Scott Marrin Inc., Riverside, CA). Processed airborne measurements are archived at http://www.atmos.umd. edu/ RAMMPP/archives/ArchiveFlightData.html (access to this website is available upon request).

RAMMPP flight plans are based on air quality forecasts, issued by the Maryland Department of the Environment (MDE), usually for days with predicted poor air quality. Most of the research flights were performed on hot summer days with weak surface winds and/or stagnation. In the past $15 \mathrm{yr}$, around 1000 research profiles (defined as a spiral over a fixed location to measure the vertical distribution of air pollutants, hereafter named research spirals) were carried out over more than 100 airports from Georgia to Vermont. Here we examine $\sim 500$ research spirals over more than 20 airports in the Baltimore/Washington airshed. Figure 1 shows the locations of the selected airports and a typical flight route. On average, $\sim 40$ research spirals were conducted each year (except 2006), providing robust statistics for long-term trend analysis (the number of research spirals per year is given in Fig. S1 of the Supplement).

To quantify the effects of regional transport and photochemical production of tropospheric ozone in the Baltimore/Washington airshed, two flights are conducted during a typical day: one flight over the upwind area in the morning and one over the downwind area in the afternoon. On 


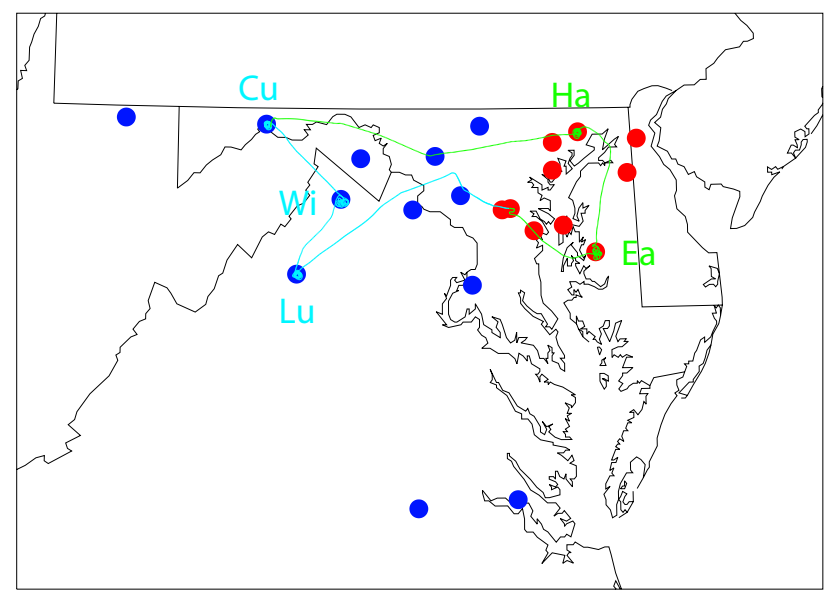

Fig. 1. Locations of the selected RAMMPP research spirals in the Baltimore/Washington airshed. Cyan and Green lines show the route of morning and afternoon flights, respectively, during a typical westerly transport flight pattern. Blue and Red dots show the locations of morning and afternoon spirals, respectively. Five airports (the spiral locations) extensively covered by this flight pattern are, from the lower left, clockwise: Luray, VA $\left(38.67^{\circ} \mathrm{N}, 78.50^{\circ} \mathrm{W}\right.$, "Lu", 65 spirals), Winchester, VA $\left(39.14^{\circ} \mathrm{N}, 78.14^{\circ} \mathrm{W}\right.$, "Wi", 57 spirals), Cumberland, $\mathrm{MD}\left(39.62^{\circ} \mathrm{N}, 78.76^{\circ} \mathrm{W}\right.$, "Cu”, 71 spirals $)$, Harford County, MD (39.57 $\mathrm{N}, 76.20^{\circ} \mathrm{W}$, "Ha", 64 spirals $)$, and Easton, MD $\left(38.80^{\circ} \mathrm{N}, 76.07^{\circ} \mathrm{W}\right.$, "Ea", 72 spirals $)$.

a typical westerly transport day (Fig. 1), the morning flight samples air over Luray, Winchester, and Cumberland in VA and western MD; the afternoon flight covers Harford County, and Easton in eastern MD. Another important process for transport of atmospheric pollutants in the mid-Atlantic region is the low level jet (LLJ) (Corsmeier et al., 1997; Higgins et al., 1997), which transports ozone and its precursors from the south. When a LLJ has been forecasted, we conduct research spirals over southern VA airports, such as Williamsburg, VA $\left(37.24^{\circ} \mathrm{N}, 76.72^{\circ} \mathrm{W}\right)$, during the morning flight. This route is called a southerly transport flights.

Generally, the air mass measured in the morning is considered as the baseline air entering the Baltimore/Washington area with residual ozone and its precursors from the previous day, while in the afternoon the observed ozone levels are regarded as the sum of residual ozone and ozone produced during the daytime. The difference between ozone measured in the morning and in the afternoon provides an estimate of the net daily production of ozone in the Baltimore/Washington area.

To interpret the trends in ozone pollution throughout the region, the column abundances of tropospheric $\mathrm{O}_{3}$ and $\mathrm{CO}$ are used. During the $15 \mathrm{yr}$ operation, research flight plans changed somewhat, e.g., the maximum height of research spirals increased from $1500 \mathrm{~m}$ above ground level (AGL) before the year 2000 to $\sim 3000 \mathrm{~m}$ AGL afterwards. In this study, tropospheric column abundances of air pollutants were obtained from altitude profiles integrated from the surface to $1500 \mathrm{~m}$ AGL, for consistency.

Numerous studies have shown that back trajectory analyses are capable of representing the general transport pathway of a hypothetical air parcel (Stohl et al., 1995; Stunder, 1996; Stohl, 1998). To study the transport of air pollutants, Hains et al. (2008) applied a hierarchical clustering technique to the RAMMPP aircraft measurements in the mid-Atlantic region for the period 1997-2003; they identified a strong correlation between integrated $\mathrm{NO}_{\mathrm{x}}$ emissions from point sources and ozone concentrations. We follow a similar approach by conducting a case study of long-term aircraft profiles over the Harford County airport (located $\sim 50 \mathrm{~km}$ to the northeast and generally downwind of Baltimore).

\section{Trends of emissions and RAMMPP aircraft measurements}

\subsection{Trends of NEI and CEMS emissions}

$\mathrm{NO}_{\mathrm{x}}$ and $\mathrm{CO}$ are important anthropogenic precursors of tropospheric ozone. Onroad and nonroad internal combustion sources release the majority of anthropogenic $\mathrm{CO}$ and around half of the anthropogenic $\mathrm{NO}_{\mathrm{x}}$, with the other half emitted from point sources such as electricity generating units, construction equipment, and other industrial sources. In this study, $\mathrm{CO}$ and $\mathrm{NO}_{\mathrm{x}}$ emissions estimates from onroad and nonroad sources were obtained from the NEI emission inventory; daily $\mathrm{NO}_{\mathrm{x}}$ emissions from point sources were acquired from CEMS measurements.

The EPA NEI program provides two emission estimates: (1) a comprehensive and detailed estimate of air pollution emissions from different sectors at county level every three years; and (2) annual estimates of national emissions, used to define national trends. The national emissions trends in mobile sources between 1997 and $2011\left(\mathrm{CO}\right.$ and $\left.\mathrm{NO}_{\mathrm{x}}\right)$ were scaled from total emissions inside the research domain based on the detailed inventory years of 2002, 2005, and 2008, in order to estimate the trends in mobile source emissions near the Baltimore/Washington airshed during the past $15 \mathrm{yr}$. We found that the research domain accounts for $\sim 4$ and $\sim 5 \%$ of the national $\mathrm{NO}_{\mathrm{x}}$ and $\mathrm{CO}$ emissions, respectively (Fig. S2 in the Supplement). Between 1997 and 2011, large decreases of $\mathrm{NO}_{\mathrm{x}}$ and $\mathrm{CO}$ emissions, $\sim 50$ and $\sim 60 \%$, respectively (using 1997 emissions as the reference values), were observed in the US (Fig. S2 in the Supplement). Here, we assume that onroad and nonroad emissions have the same trends in the research domain as for the entire US; consequently, the large reductions of precursor emissions should affect tropospheric ozone in the Baltimore/Washington airshed. 


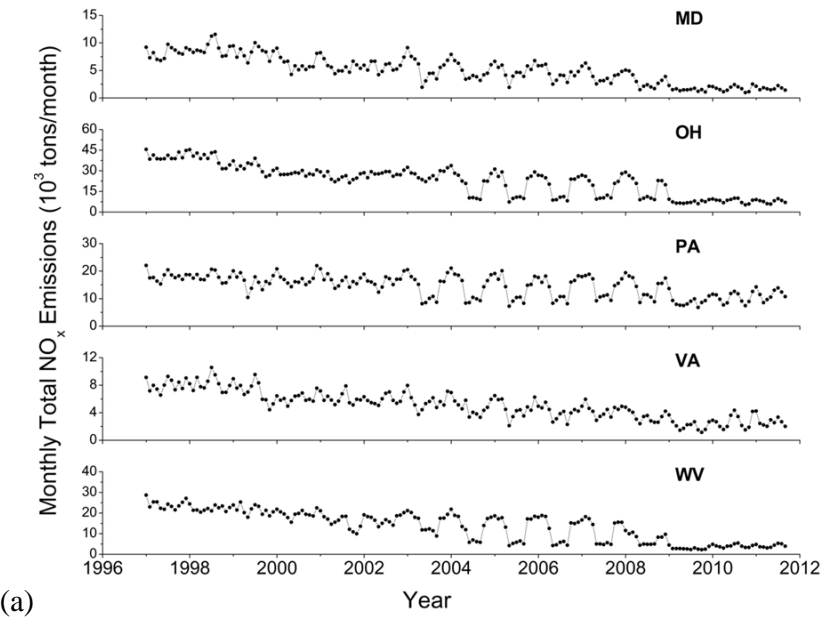

(a)

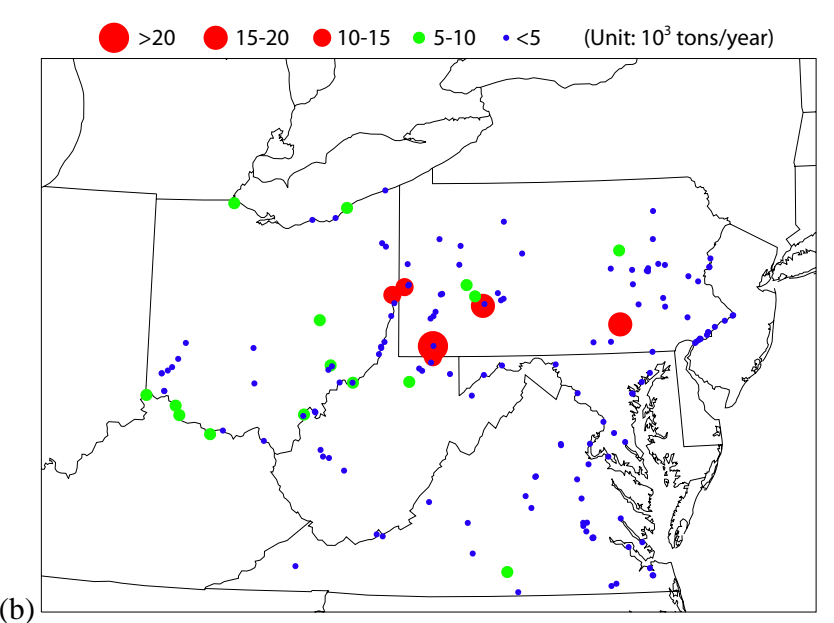

(b)

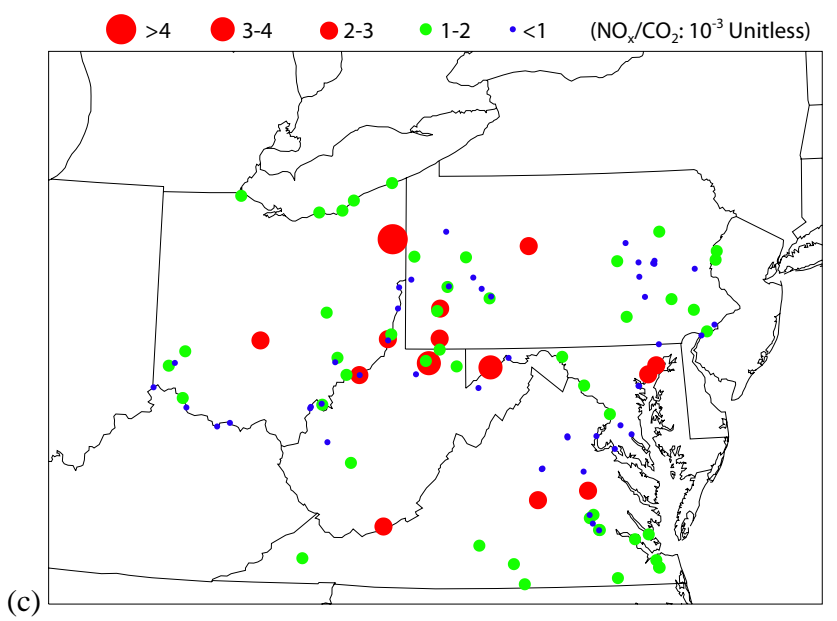

Fig. 2. CEMS emissions of $\mathrm{NO}_{\mathrm{x}}$ in the research domain: (a) longterm trends of monthly $\mathrm{NO}_{\mathrm{x}}$ emissions (unit: $10^{3}$ tons) from various states; (b) locations of major $\mathrm{NO}_{\mathrm{x}}$ point sources, with color and size of circle reflecting the magnitude of emission (as indicated); (c) map of $\mathrm{NO}_{\mathrm{X}} / \mathrm{CO}_{2}$ ratios (unit: mol mol ${ }^{-1}$ ). (b) and (c) are based on the annual emissions data in 2010.
Long-term trends in monthly CEMS data (Fig. 2a) show that $\mathrm{NO}_{\mathrm{x}}$ emissions from point sources decreased by $\sim 80 \%$ from 1997 to 2011 for each state, except for PA, where they decreased by only $\sim 50 \%$ (using 1997 emissions as a baseline). Several characteristics are observed: (1) between 1997 and 2002, a gradual decrease of $\mathrm{NO}_{\mathrm{x}}$ emissions for all states; (2) a large reduction after 2003, due to the EPA $\mathrm{NO}_{\mathrm{x}}$ State Implementation Plan (SIP) Call; (3) a square wave pattern in $\mathrm{NO}_{\mathrm{x}}$ emissions from $\mathrm{OH}, \mathrm{PA}$, and WV between 2003 and 2009 when $\mathrm{NO}_{\mathrm{x}}$ in these states was only controlled during the ozone season; and (4) through 2003-2008 further slow decreases for all states, followed by substantial reductions in $\mathrm{MD}, \mathrm{OH}$, and $\mathrm{WV}$, and slight increases in PA and VA after 2009. During the same period, $\mathrm{CO}_{2}$ emissions from these point sources, representing the total amount of fossil fuel burned, stayed flat (Fig. S3 in the Supplement). Emissions of $\mathrm{NO}_{\mathrm{x}}$ from point sources are regulated by the EPA $\mathrm{NO}_{\mathrm{x}}$ Budget Trading Program (NBP), later superseded by the Clean Air Interstate Rule (CAIR) (EPA, 2009; Butler et al., 2011), which covers 27 eastern states and the District of Columbia (http://www.epa.gov/cair/). These EPA programs regulated power plant emissions in the past $15 \mathrm{yr}$, and the $\mathrm{NO}_{\mathrm{x}}$ SIP call substantially reduced the $\mathrm{NO}_{\mathrm{x}}$ emissions from point sources in the research domain starting in 2003.

Figure $2 \mathrm{~b}$ presents locations of the major point sources of $\mathrm{NO}_{\mathrm{x}}$ in the Ohio River valley and western PA. These air pollutants released upwind of the Baltimore/Washington airshed exert a significant influence on downwind air quality under the prevailing westerly winds during the ozone season (Marufu et al., 2004; Frost et al., 2006; Kim et al., 2006). We also computed the ratio of $\mathrm{NO}_{\mathrm{x}}$ and $\mathrm{CO}_{2}$ emissions for each source. Figure $2 \mathrm{c}$ shows that the point sources with high $\mathrm{NO}_{x} / \mathrm{CO}_{2}$ ratios exist mainly in the Ohio River valley, and these "hot spots" (details given in Table $\mathrm{S} 3$ in the Supplement) are suitable targets for future $\mathrm{NO}_{\mathrm{x}}$ emission reductions.

\subsection{Trends of ground-level observations}

To study ozone photochemistry, we analyzed the EPA CO, $\mathrm{NO}_{\mathrm{x}}$, and $\mathrm{O}_{3}$ observations in the afternoon (12:00-18:00 LT (Eastern Standard Time, EST)) during the ozone season. $\mathrm{O}_{3}$ monitors are located throughout this area, while $\mathrm{CO}$ and $\mathrm{NO}_{\mathrm{x}}$ observations are mainly along the Interstate 95 corridor between Baltimore and Washington, DC (Fig. S4 in the Supplement). Figure 3 shows the long-term trends of annual mean ground-level concentrations of air pollution during the summer. The long-term ozone measurements show large interannual variations because ozone production is not only determined by emissions but also weather, especially temperature (EPA, 2006). A discernible decrease $\left(\sim 0.6 \mathrm{ppbv} \mathrm{yr}^{-1}\right.$, Fig. 4) is observed suggesting a general decreasing trend of ambient ozone in the Baltimore/Washington area, similar to decreasing trends reported across the eastern US (Lefohn et al., 2010; Cooper et al., 2012). 


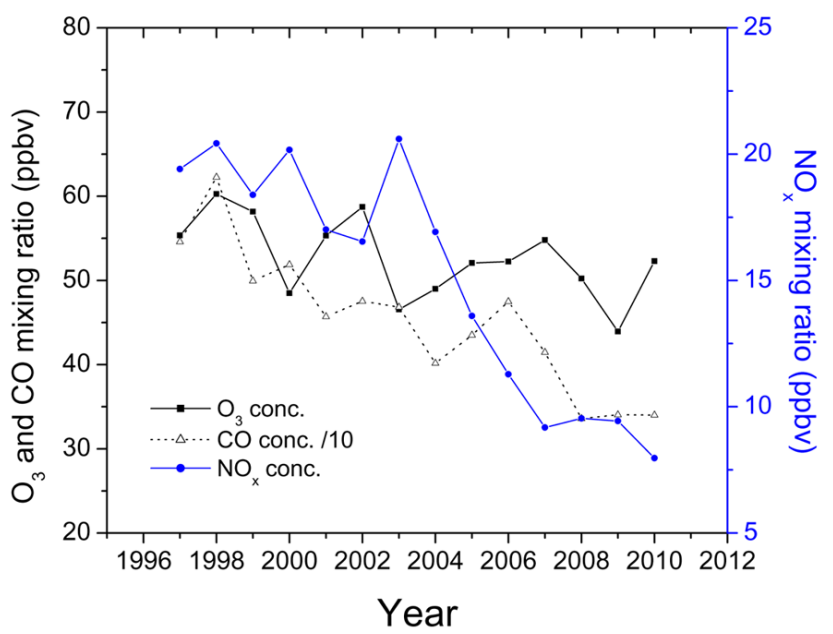

Fig. 3. Long-term trends of ground-level $\mathrm{O}_{3}, \mathrm{CO}$, and $\mathrm{NO}_{\mathrm{x}}$ observed in the Baltimore/Washington area in EPA AQS sites (sites shown in Fig. S4 of the Supplement). CO mixing ratios have been scaled by 10 for clarity. To investigate the ozone chemistry, measurements in the afternoon (12:00-18:00 LT) during the ozone seasons were used to calculate annual means.

Long-term ground-level $\mathrm{CO}$ observations show a nonmonotonic but steadily decreasing trend from $\sim 600$ to $\sim 350 \mathrm{ppbv}$ or $\sim 18 \mathrm{ppbv} \mathrm{yr}^{-1}$ decrease (linear regression coefficient $r=-0.90$ ). If the regional baseline $\mathrm{CO}$ mixing ratio is assumed to be $\sim 150 \mathrm{ppbv}$, then the reduction in the added regional $\mathrm{CO}$ mixing ratio is from $\sim 450$ to $\sim 200 \mathrm{ppbv}$, corresponding to a $\sim 55 \%$ decrease since 1997 . During the same period, the NEI annual $\mathrm{CO}$ emissions decreased from $\sim 13.5 \times 10^{6}$ to $\sim 5.5 \times 10^{6}$ tons (Fig. S2 in the Supplement), a $\sim 59 \%$ decrease since 1997 . Therefore, after correcting for baseline $\mathrm{CO}$, the trends of ground-level $\mathrm{CO}$ observations and the NEI CO emissions are similar.

Long-term ambient $\mathrm{NO}_{\mathrm{x}}$ measurements demonstrated a sharp decrease (from $\sim 20$ to $\sim 8$ ppbv) after 2003 , while annual NEI emissions (CEMS data plus automobile emissions) declined gradually. This sharp decrease coincides with the large reduction of point source emissions of $\mathrm{NO}_{\mathrm{x}}$ during the EPA $\mathrm{NO}_{x}$ SIP call (Fig. 2a). Here we estimate daily mean $\mathrm{NO}_{\mathrm{x}}$ emissions during the ozone season by incorporating daily CEMS emissions (point sources) and scaled mobile emission estimates from national NEI annual data (4\% of the total emissions in the US). Figure 5 indicates that total emissions from both point sources and mobile sources decreased significantly, $\sim 60$ and $\sim 50 \%$, respectively. Point source emissions exhibited a sharp decrease around 2003 due to the EPA $\mathrm{NO}_{\mathrm{x}}$ SIP call, while mobile emissions decreased gradually. The contribution of $\mathrm{NO}_{\mathrm{x}}$ from point sources in this region to the total emissions decreases from $\sim 70 \%$ in the late 1990 s to $\sim 50 \%$ in the early 2010 s, which confirms the efficacy of the EPA $\mathrm{NO}_{\mathrm{x}}$ SIP call.

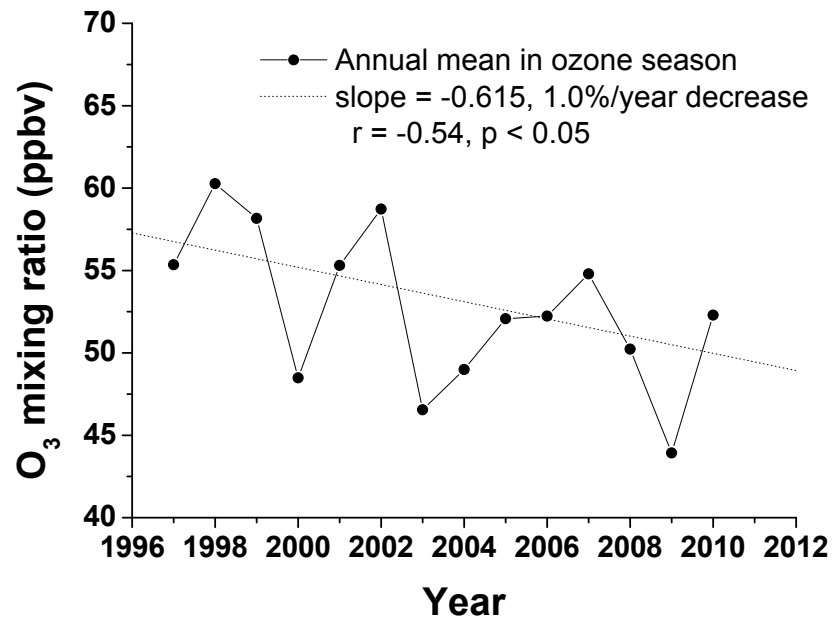

Fig. 4. Linear regression analysis of long-term EPA AQS observations of surface ozone in the Baltimore/Washington area. Ozone data are the same as in Fig. 3; and the linear regression of ozone is with respect to year.

We compared the CEMS, scaled NEI, and total $\mathrm{NO}_{\mathrm{x}}$ emissions with EPA AQS observations using linear regression analysis (Fig. 6), revealing good correlation between these emission estimates and ground-level $\mathrm{NO}_{\mathrm{x}}$ observations. The slope of observations versus emissions is $0.0042 \mathrm{ppbv}^{-1}$ for CEMS and $0.0024 \mathrm{ppbv} /$ ton for NEI mobile emissions alone. Therefore, if we assume emissions from point sources and mobile sources have an equivalent effect on surface concentrations of $\mathrm{NO}_{\mathrm{x}}$, point sources contribute $\sim 60 \%$ of the ambient ground-level $\mathrm{NO}_{\mathrm{x}}$ concentrations. The daily average CEMS measurements provide a unique opportunity to investigate the effects of emissions on surface $\mathrm{NO}_{\mathrm{x}}$ observations. Considering that ground-level $\mathrm{NO}_{\mathrm{x}}$ concentrations are controlled by other parameters such as advection, temperature, turbulence, and concentration of VOCs, the CEMS data correlate surprisingly well with observed ground-level $\mathrm{NO}_{\mathrm{x}}$ concentrations.

\subsection{Trends of aircraft measurements}

\subsubsection{Vertical distribution of tropospheric $\mathrm{O}_{3}$ and $\mathrm{CO}$}

Long-term aircraft measurements show that tropospheric ozone has large day-to-day variations; to illustrate this, all aircraft measurements of tropospheric ozone obtained in the summer of 2001 are shown in Fig. 7. In the lower atmosphere, ozone is reasonably well mixed with a local maximum near $1000 \mathrm{~m}$ AGL, around the top of planetary boundary layer (PBL). In the morning upwind flights (Fig. 7b), ozone mixing ratios near the surface are relatively low compared with the values in the FT (higher than $1000 \mathrm{~m}$ ), suggesting that ozone is lost due to dry deposition and reactions with $\mathrm{NO}_{\mathrm{x}}$ during the night. With low photochemical production rates and weak mixing in the morning, ozone 


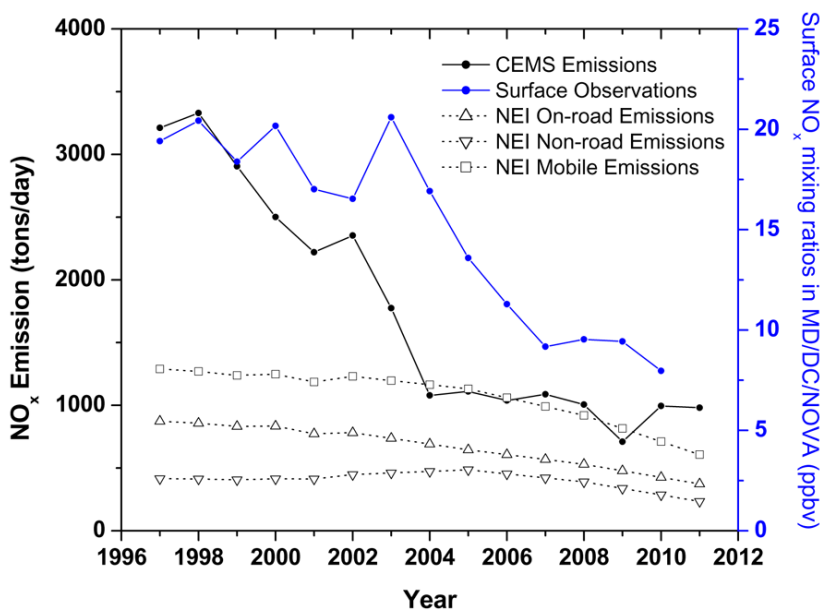

Fig. 5. Long-term trends of annual mean estimated daily emissions of $\mathrm{NO}_{\mathrm{x}}$ (CEMS and yearly NEI in the research domain scaled to more detailed inventories from 2002, 2005, and 2008) and EPA AQS ground-level observations of $\mathrm{NO}_{\mathrm{x}}$ in the Baltimore/Washington area. NEI mobile emissions are the sum of onroad and nonroad mobile emissions.

mixing ratios stay low until close to noon. Relatively high concentrations of ozone observed in the FT are in the residual layer, reflecting ozone production on previous days (Yorks et al., 2009). With the rise of the PBL during daytime, air in the residual layer is entrained and mixed, transporting the residual-layer pollutants downward. In the afternoon, tropospheric ozone is produced through photochemical reactions throughout the PBL and lower FT; the mean ozone altitude profile shows a quasi-uniform concentration (Fig. 7c). The afternoon mean ozone profile also has a local maximum at $\sim 1000 \mathrm{~m}$, with ozone $\sim 18 \mathrm{ppbv}$ higher than the groundlevel value. Pollutants aloft observed in both morning and afternoon do not immediately influence local air quality, but transport of these pollutants exerts significant effects on air pollution in downwind areas.

We conducted a similar analysis on all the $\mathrm{CO}$ profiles obtained in 2001 (Fig. 8). A relatively uniform mixing ratio of $\sim 250$ ppbv $\mathrm{CO}$ was observed in the FT, and maximum $\mathrm{CO}$ concentrations were observed near the surface. The $\mathrm{CO}$ mixing ratios observed in the FT during summer 2001 are consistent with previous observations at high elevation in western VA (Hallock-Waters et al., 1999). These measurements reflect atmospheric CO sources on the Earth's surface and on average an exponential decrease within the PBL. With a lifetime of about one month, $\mathrm{CO}$ can be transported upward and well mixed in the FT, so CO is a good chemical tracer to investigate advection in the lower atmosphere (Castellanos et al., 2011; Loughner et al., 2011). The mean CO profiles from upwind and downwind research spirals exhibit similar vertical distributions (Fig. S5 in the Supplement), indicating that $\mathrm{CO}$ pollution in the Baltimore/Washington airshed is a regional problem.

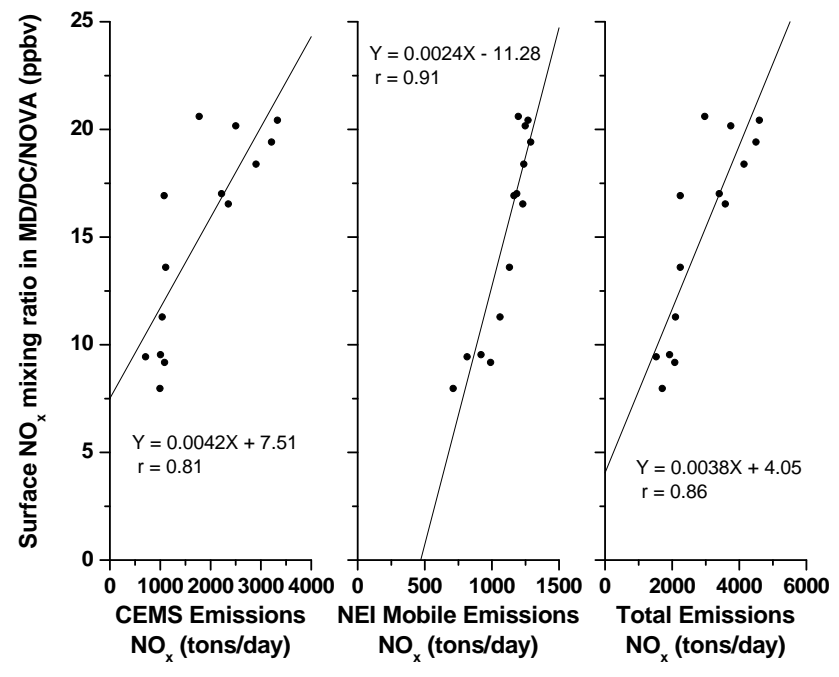

Fig. 6. Linear regression analysis of the long-term CEMS, NEI, and (CEMS + NEI) $\mathrm{NO}_{\mathrm{x}}$ emissions with EPA AQS observations; left: CEMS emissions only; middle: NEI mobile emissions (interpolated from triennial inventories to annual estimates) only; right: total emissions (CEMS emissions + NEI mobile emissions).

\subsubsection{Estimate of photochemical production of tropospheric ozone}

Ozone production is closely related to temperature (EPA, 2006; Camalier et al., 2007; Bloomer et al., 2009; Jacob and Winner, 2009), so we must take the inter-annual variations of ambient temperature into account to study the long-term trend of tropospheric ozone. Here, we use the climate penalty factor $(\mathrm{CPF})$, defined as $\frac{\mathrm{d}\left[\mathrm{O}_{3}\right]}{\mathrm{d} T}$. One previous study reported $\mathrm{CPF}$ as $\sim 3.2 \mathrm{ppbv}^{\circ} \mathrm{C}^{-1}$ prior to 2002 and $\sim 2.2 \mathrm{ppbv}^{\circ} \mathrm{C}^{-1}$ after 2002 in the eastern US (Bloomer et al., 2009). Here, we first calculated a "standard" temperature vs. altitude profile by averaging all the temperature profiles. We then normalized ozone mixing ratio profiles by applying the CPF (3.2 $\mathrm{ppbv}^{\circ} \mathrm{C}^{-1}$ before 2002 and $2.2 \mathrm{ppbv}^{\circ} \mathrm{C}^{-1}$ after 2002) to the differences from the "standard" temperature profile and calculated column ozone.

Figure 9 shows the long-term trend of lower tropospheric ozone column abundances after adjustment for variations in temperature using the $\mathrm{CPF}$. The upwind ozone column abundances are taken as the baseline ozone profile entering the Baltimore/Washington area, with ozone mainly in the residual layer; the downwind column abundances represent the total of baseline ozone plus ozone generated by local photochemical reactions. The afternoon flights usually finish around 16:00 LT, when ozone reaches its maximum, so the difference between morning and afternoon flights represents the daily production of tropospheric ozone in the Baltimore/Washington area. Negative values are observed for 1999 and 2008, when a relatively small number of research flights were conducted. 
The mean net production in the past $15 \mathrm{yr}$ is estimated as $2.3 \pm 2.0 \mathrm{DU} \mathrm{day}^{-1}\left(1 \mathrm{DU}=2.69 \times 10^{16} \mathrm{~mol} \mathrm{~cm}^{-2}\right)$, where $2.0 \mathrm{DU}$ represents the $\pm 1 \sigma$ variability. When assuming ozone is well-mixed in the lower $1500 \mathrm{~m}$, this value equals $\sim 15 \pm 13$ ppbv of ozone production.

It is notable that the net daily production of ozone decreased from $\sim 3.0 \mathrm{DU} \mathrm{day}^{-1}$ in the late $1990 \mathrm{~s}$ to $\sim 1.0 \mathrm{DU} \mathrm{day}^{-1}$ in the early 2010 s, corresponding to $\sim 20$ to $\sim 7$ ppbv day $^{-1}$, respectively. This shows that the daily ozone production within the Baltimore/Washington area has decreased significantly, $\sim 60 \%$ in total or $\sim 1.0 \mathrm{ppbv} \mathrm{yr}^{-1}$. This magnitude of decrease is higher than the decreasing trends observed in ground-level measurements (Fig. 4). The ground-level measurements were collected during the whole ozone season, while the RAMMPP research flights were only conducted on air pollution action days when the transport is forecasted to play an important role in the episodic ozone pollution, either under westerly transport or southerly transport patterns. These results suggest that ozone transported into the Baltimore/Washington airshed plays an important role in determining downwind ozone pollution; likewise, emissions in Baltimore can impact air quality over downwind areas such as Philadelphia. Since most of the RAMMPP research flights were conducted on poor air quality days, our estimates can be treated as the upper limit of net daily production of ozone in the Baltimore/Washington airshed.

\subsubsection{Long-term trends of tropospheric $\mathrm{O}_{3}$ and $\mathrm{CO}$}

Here we focus on $\mathrm{O}_{3}$ and $\mathrm{CO}$ measurements on afternoon flights, when maximum ground-level ozone is usually observed. The annual mean $\mathrm{O}_{3}$ and $\mathrm{CO}$ column abundances are plotted, showing their long-term trends in Fig. 10. We used the Savitzky-Golay Smoothing technique (Savitzky and Golay, 1964; Bromba and Ziegler, 1981; Gorry, 1990), which preserves the temporal features of the data while reducing the influences of noise and missing data. Figure 10a shows $\mathrm{a} \sim 0.2 \mathrm{DU} \mathrm{yr}^{-1}$ decrease in ozone column abundances. Assuming ozone in the lower $1500 \mathrm{~m}$ is well mixed, this decrease of column ozone is equivalent to $\sim 1.3 \mathrm{ppbv} \mathrm{yr}^{-1}$ throughout this part of the atmosphere. This value is much higher than $\mathrm{a} \sim 0.4$ to $0.6 \mathrm{ppbv} \mathrm{yr}^{-1}$ decrease of groundlevel ozone reported in the eastern US (Bloomer et al., 2010; Cooper et al., 2012). The explanation of this difference could be that RAMMPP research flights were usually conducted on air quality action days, suggesting that for these conditions (i.e., meteorological conditions conducive to poor air quality) ozone pollution has improved more than under others. Cooper et al. (2012) observed a $\sim 15$ ppbv decrease in the 95th percentile of eastern US summertime ozone from the early 1990s to the late 2000s. These results are consistent with the results from our long-term RAMMPP aircraft measurements.

To test the effects of variations of ambient temperature, we also calculated the trends in long-term ozone column abun-

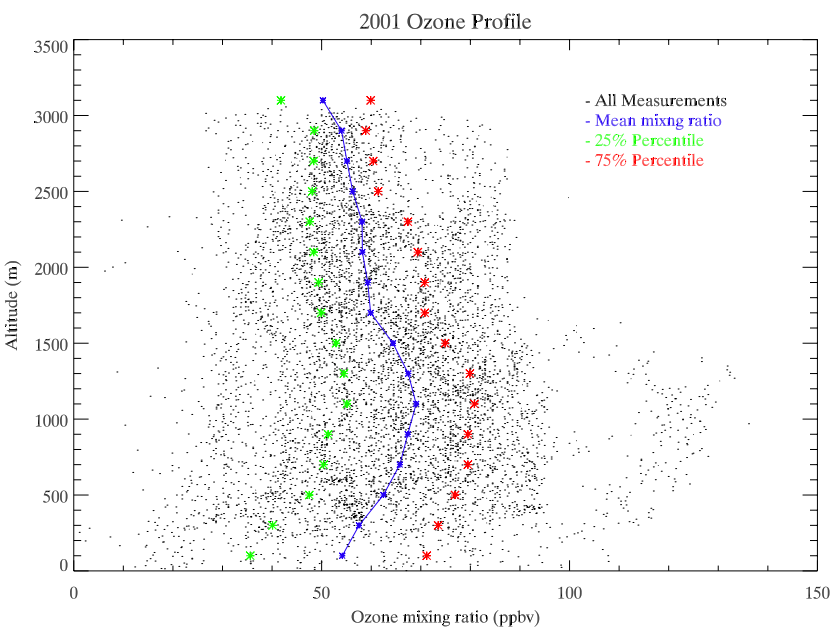

(a)

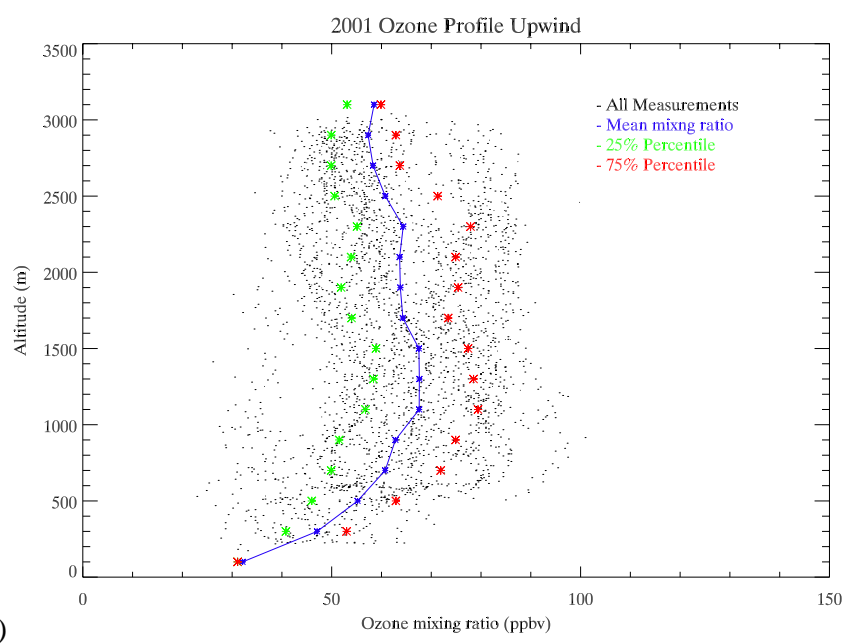

(b)

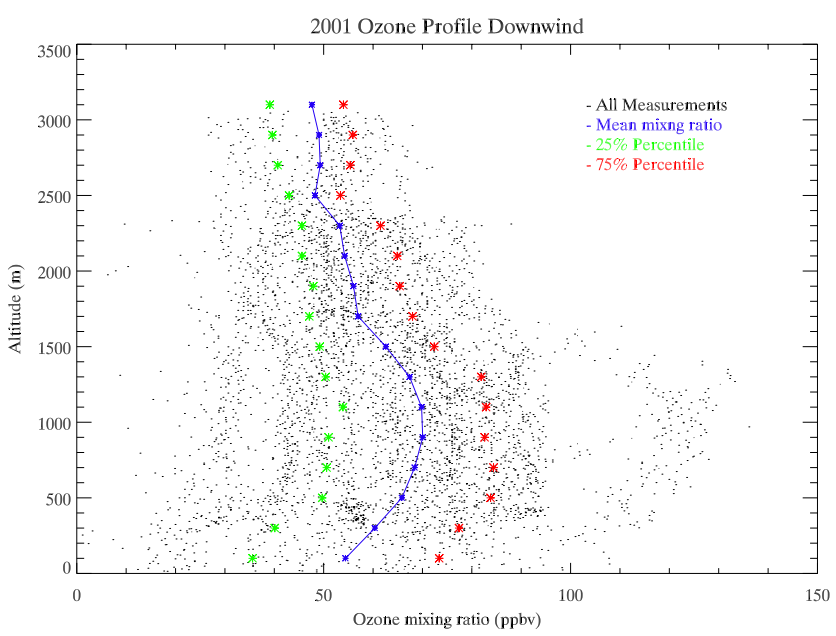

Fig. 7. Vertical distributions of tropospheric ozone over the Baltimore/Washington region in 2001: (a) all spirals; (b) upwind spirals; (c) downwind spirals. Measurements are grouped every $200 \mathrm{~m}$ according to the altitude; the 25 th percentile, mean, and 75 th percentile are shown for each layer. 


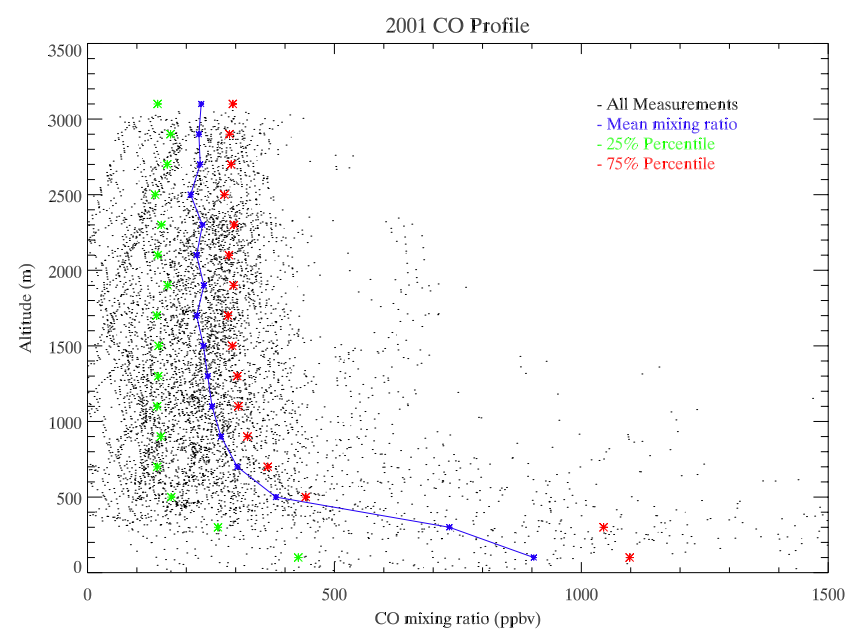

Fig. 8. Vertical distributions of tropospheric $\mathrm{CO}$ over the Baltimore/Washington region in 2001 (all spirals). The 25 th percentile, mean, and 75th percentile are shown as in Fig. 7.

dances without applying the CPF (Fig. 10b). The difference between the ozone column abundances with and without CPF adjustment is discernible, especially for years 2009 to 2011 . Figure $10 \mathrm{~b}$ shows a monotonic increase of column ozone from 2009 to 2011, suggesting an increasing trend. However, the statistics of daily mean temperature show that the summer of 2009 has far less hot days, especially when compared with the hot summers of 2010 and 2011 (Fig. S6 in the Supplement). After compensating for the effects of ambient temperature with the CPF, the ozone column abundances in 2010 and 2011 decreased, and the increasing trend in ozone over those years disappeared.

The long-term $\mathrm{CO}$ column abundances show a $\sim 0.8 \mathrm{DU} \mathrm{yr}^{-1}$ decrease (Fig. 10c). As shown in Fig. 8, CO concentrations decay exponentially above the surface within the PBL to a near constant value aloft. So the $0.8 \mathrm{DU} \mathrm{yr}^{-1} \mathrm{de}-$ crease in column $\mathrm{CO}$ can be interpreted as a $\sim 35 \mathrm{ppbv} \mathrm{yr}^{-1}$ decrease at the ground level, less than the nationwide decrease (data available at http://www.epa.gov/airtrends/). One possible explanation is that the national trend is calculated based on the $2 \mathrm{nd}$ maximum of annual $8 \mathrm{~h}$ average, i.e., measurements in $\mathrm{CO}$ episodes, which usually arise on cold winter days with a temperature inversion. RAMMPP research flights are normally carried out during the ozone season, when $\mathrm{CO}$ pollution is not as severe and strong convection can transport $\mathrm{CO}$ upward. Figure 10 also shows that $\mathrm{O}_{3}$ and $\mathrm{CO}$ column abundances are correlated, in particular after the EPA $\mathrm{NO}_{\mathrm{x}}$ SIP call. For instance, in 2009, both high $\mathrm{CO}$ and high $\mathrm{O}_{3}$ column abundances were observed. These large inter-annual variations in column CO cannot be explained by NEI emissions trends (Fig. S2) and have not been observed by ground-level observations (Schwab et al., 2009). $\mathrm{CO}$ is usually emitted alongside with $\mathrm{NO}_{\mathrm{x}}$ from automobile emissions or other incomplete combustion such

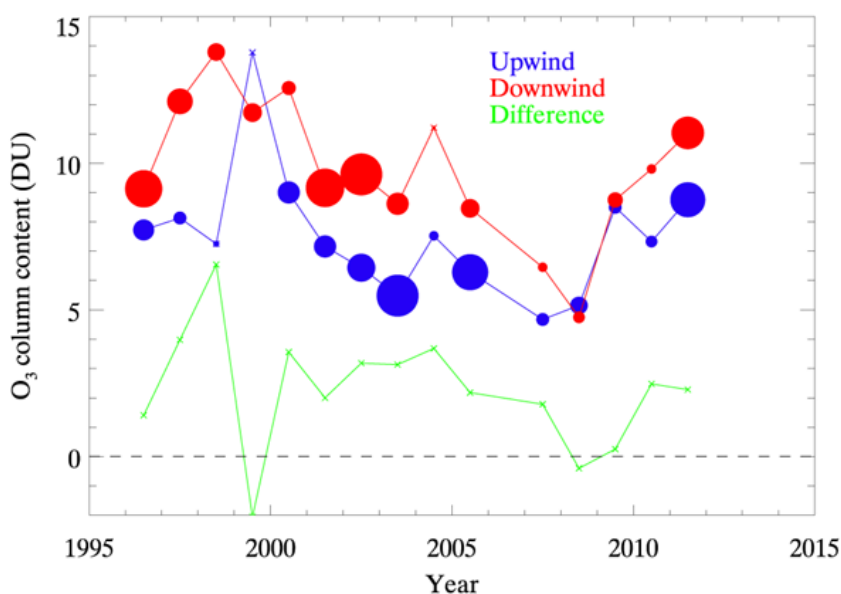

Fig. 9. Lumped long-term annual mean tropospheric ozone column abundances in the lowest $1500 \mathrm{~m}$. The size of each circle is proportional to the number of research spirals for a specific summer. Blue and Red circles show the mean column ozone in upwind and downwind regions, respectively. The green line shows the difference between upwind and downwind columns.

as biomass burning. Therefore, a high concentration of $\mathrm{CO}$ might be an indicator of high $\mathrm{NO}_{\mathrm{x}}$, which would also boost the production of ozone in the largely $\mathrm{NO}_{\mathrm{x}}$-limited eastern US. Airborne $\mathrm{NO}_{2}$ measurements were not available from RAMMPP aircraft before 2011. Thus, this hypothesis of intercepting automobile exhaust or wildfire plumes cannot be verified. However, when we used the 7 yr Savitzky-Golay method to smooth the data, the $\sim 0.8 \mathrm{DU} \mathrm{yr}^{-1}$ decrease, $\sim 15 \%$ relatively, can be treated as the long-term trend of column $\mathrm{CO}$ in the lower atmosphere, subject to the uncertainties associated with limited airborne sampling.

To investigate the long-term $\mathrm{CO}$ trends from space, we used the monthly MOPITT near-surface CO retrievals from 2000 to 2011 (Deeter et al., 2003, 2012). Since the MOPITT Equator crossing time is around 10:30 LT, we used the morning RAMMPP CO column abundances observed in western MD. Only data in summer (JJA) were selected to reduce the effect of $\mathrm{CO}$ seasonal variations. Figure 11 shows the observed annual mean. The oxidation of VOCs is an important source of tropospheric CO; in the eastern US, biogenic VOC emissions such as isoprene dominate (Kesselmeier and Staudt, 1999). We assume that the amount of CO oxidized from VOCs has not changed in the past $15 \mathrm{yr}$, so the $\mathrm{CO}$ trends are only discussed with reference to anthropogenic $\mathrm{CO}$ emissions in this study. Linear regression analyses of long-term EPA AQS observations, RAMMPP aircraft measurements, MOPITT observations, and NEI emissions were conducted, with high correlation of concentrations $(Y)$ as a function of time $(X)$ : for AQS $(r=-0.89)$, MOPITT observations $(r=-0.86)$ and NEI emissions $(r=-0.99)$. However, the correlation is low for RAMMPP aircraft measurements in the morning, which could be caused by the sampling 
Table 1. Characteristics and emission estimates of each cluster. Correlation coefficients are for lower tropospheric column ozone over Maryland, regressed against emissions.

\begin{tabular}{lllrr}
\hline Cluster & Upwind states & Emissions estimate & $r^{\mathrm{b}}$ & $n^{\mathrm{c}}$ \\
\hline 1 & $\mathrm{OH}$ and PA & $\mathrm{MD}_{i}+0.5 \mathrm{PA}_{i-1}+0.25 \mathrm{OH}_{i-1}$ & 0.86 & 18 \\
2 & $\mathrm{PA}$ & $\mathrm{MD}_{i}+0.5 \mathrm{PA}_{i-1}$ & 0.16 & 22 \\
3 & $\mathrm{WV}$ or VA & $\mathrm{MD}_{i}+0.5 \mathrm{VA}_{i-1}$ or $\mathrm{MD}_{i}+0.5 \mathrm{WV}_{i-1}$ & -0.08 & 12 \\
4 & Recirculation & $\mathrm{MD}_{i}+0.5 \mathrm{VA}_{i-1}+0.5 \mathrm{PA}_{i-1}$ & 0.53 & 4 \\
5 & Stagnation $^{\mathrm{a}}$ & $\mathrm{MD}_{i}$ & 0.04 & 7 \\
\hline
\end{tabular}

a The background flight (conducted on 3 September 2009) was incorporated into the stagnation cluster because it shares the same estimate of upwind emissions; ${ }^{\mathrm{b}}$ linear regression coefficient $r$ is calculated for each group in Fig. 13a; ${ }^{c}$ number of research spirals.

uncertainty mentioned above. The overall reduction (relative to year of 2000$)$ is estimated as $\sim 40 \%\left(\sim 3.5 \% \mathrm{yr}^{-1}\right)$ for AQS observations, RAMMPP measurements, and MOPITT observation, compared to $\sim 60 \%\left(\sim 4.5 \% \mathrm{yr}^{-1}\right)$ for the NEI emissions. The decreasing trend of MOPITT CO observed over western $\mathrm{MD}, \sim 3.5 \% \mathrm{yr}^{-1}$, is higher than the value $\left(\sim 1.5 \% \mathrm{yr}^{-1}\right)$ reported in the eastern US (Worden et al., 2013). However, in Worden et al. (2013), MOPITT total column CO data in all seasons were analyzed, while this study only focused on summertime observations of near-surface $\mathrm{CO}$. We would expect to see a larger trend in near-surface concentrations compared to total column $\mathrm{CO}$ because the near-surface $\mathrm{CO}$ is substantially influenced by surface-based pollution sources (Fig. 8).

\section{Clustering analysis on the regional transport of CEMS emissions}

The CEMS program monitors emissions from point sources equipped with tall smokestacks, such as power plants and industrial boilers. A study conducted by the US Government Accountability Office (US GAO) tracked 284 tall smokestacks at 172 coal-fired power plants in 34 states, of which 205 are 62.5 to $213 \mathrm{~m}$ tall, 63 are 213 to $305 \mathrm{~m}$ tall, and 12 are higher than $305 \mathrm{~m}$ (GAO, 2011). About onethird of these tall stacks are located in PA, WV and $\mathrm{OH}$ along the Ohio River valley. Such high smokestacks can disperse air pollutants over great distances. Since the Baltimore/Washington region is often downwind of the Ohio River valley, emissions from point sources are expected to exert substantial influence on downwind air quality. We aggregated the CEMS emission data by state, because point sources are regulated by each state.

We studied regional transport with a hierarchical clustering technique using measurements from 63 RAMMPP research spirals over Harford County airport from 1998 to 2011. We utilized the National Oceanic and Atmospheric Administration (NOAA) Air Resource Laboratory (ARL) Hybrid Single-Particle Lagrangian Integrated Trajectory (HYSPLIT) model (version 4, http://www.arl.noaa.gov/

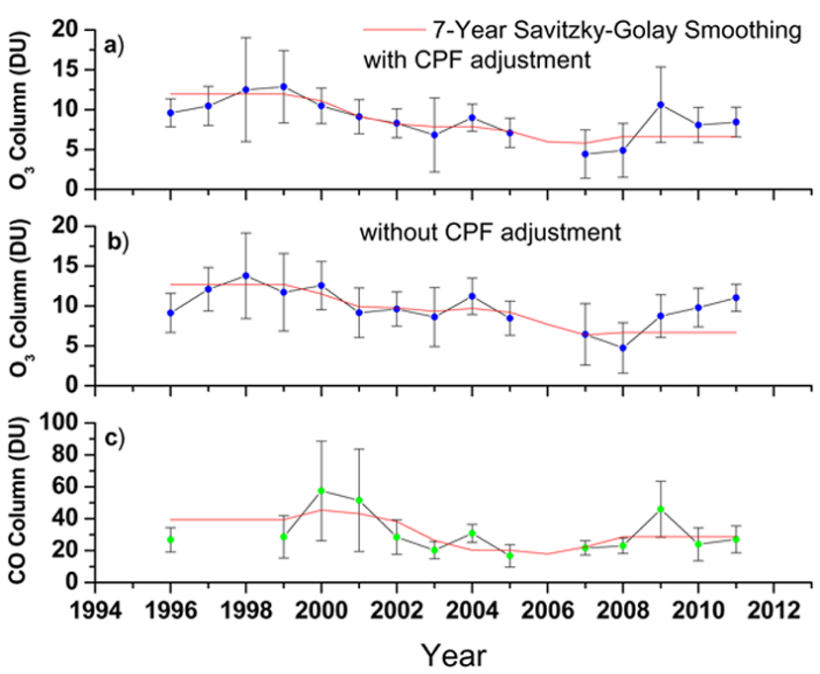

Fig. 10. Long-term trends of annual mean afternoon $\mathrm{O}_{3}$ and $\mathrm{CO}$ column abundances (from the surface to $1500 \mathrm{~m}$ AGL) over the region downwind of the Baltimore/Washington area: (a) column $\mathrm{O}_{3}$ with $\mathrm{CPF}$ adjustment; (b) column $\mathrm{O}_{3}$ without $\mathrm{CPF}$ adjustment; (c) column CO. Error bars represent one standard deviation. The red lines are with the $7 \mathrm{yr}$ Savitzky-Golay smoothing.

ready/hysplit $4 . \mathrm{html}$ ) to calculate $48 \mathrm{~h}$ back trajectories. The time of each aircraft spiral was used to initialize each back trajectory with release heights of 500,1000, and $1500 \mathrm{~m}$ AGL, respectively. Details on the model and meteorological fields are given in Table S4 of the Supplement. The accuracy of these trajectories is adequate to distinguish various transport pathways of air pollutants that reach the Baltimore/Washington airshed (Stohl et al., 1995; Stohl, 1998).

Location and altitude information of each HYSPLIT back trajectory was archived and back trajectories ending at $1000 \mathrm{~m}$ over Harford County airport were classified based on air mass origin, as show in Fig. 12. Three major clusters of air mass origin, denoted OH/PA, PA, and WV/VA, arose from the analysis. Two minor clusters, recirculation and stagnation (containing less than 10 members each), are embedded underneath these spaghetti-like clusters (Table 1). 


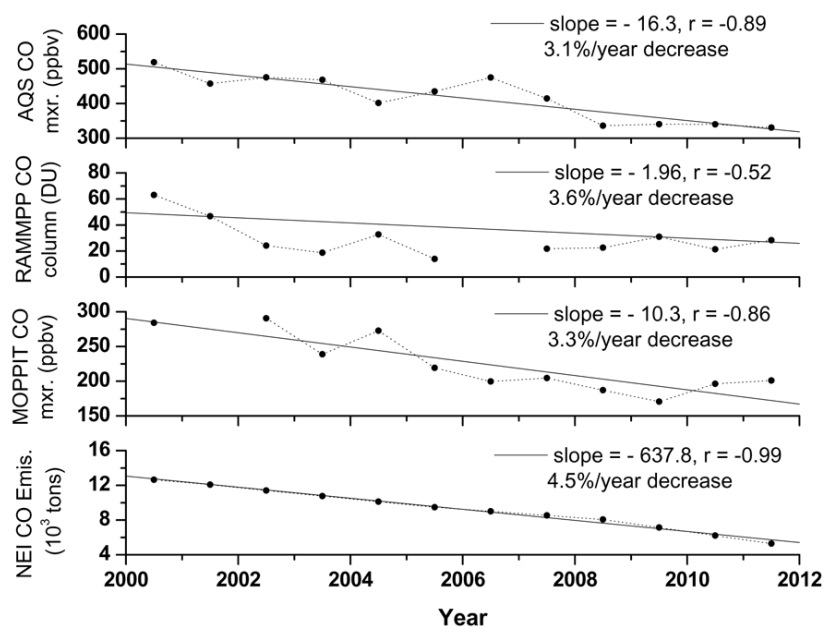

Fig. 11. The long-term trends of summertime AQS observations, RAMMPP measurements, MOPITT observations, and NEI emissions: (a) annual mean AQS CO mixing ratios; (b) annual mean RAMMPP morning column CO over western MD; (c) annual mean MOPITT near-surface CO mixing ratios; (d) annual NEI emissions. Lines show the results of linear regression analyses.

Here we establish a "conceptual" model to evaluate the relationship between the upwind power plant emissions of $\mathrm{NO}_{\mathrm{x}}$ and downwind ozone pollution. Previous studies suggest that single back trajectories might not be sufficient to relate the upwind sources to downwind pollution (Stohl et al., 2002, 2003). For this analysis, we focus on transport from upwind sources over a $24-48 \mathrm{~h}$ period of time, much shorter than the period of time considered by Stohl et al. $(2002,2003)$. Our comparison of single back trajectories and 27 member back trajectory ensembles from HYSPLIT demonstrates that single back trajectories can accurately represent the ensemble behavior over the period of time important for our analysis (Fig. S7 in the Supplement). Precise determination of the relationship between upwind sources and downwind pollution is complicated by the release altitude of $\mathrm{NO}_{\mathrm{x}}$ from power plants mostly at 200-300 m AGL (GAO, 2011), followed by a small-scale, rapid-plume rise that is difficult to quantify. Nonetheless, we have used HYSPLIT to show that the $24 \mathrm{~h}$ backward concentration dispersion of air pollutants observed by the RAMMPP aircraft occurs for emissions over a region comparable to the area of a state (Fig. S8 in the Supplement). The "conceptual" model approach described below demonstrates the general, quantitatively consistent nature of the relationship between upwind sources and downwind pollution. The more precise determination of this relationship would benefit from a Lagrangian particle dispersion model and cluster analysis treatment, such as described by Stohl et al. (2002, 2003); this type of analysis is beyond the scope of our present study. The "conceptual" model that relates upwind sources at a state level to downwind pollution is of great use to air quality managers.
The $\mathrm{OH} / \mathrm{PA}$ cluster corresponds to the prevailing westerly winds during the ozone season. Emissions of $\mathrm{NO}_{\mathrm{x}}$ from $\mathrm{OH}$ and PA are $\sim 4$ and $\sim 6$ times higher than emissions from MD (Fig. 2a). A simplified approach was developed to evaluate the influence of upwind emissions: if the back trajectory passes over $\mathrm{OH}$ and PA, total emissions are estimated as

$$
\begin{aligned}
\text { Emission }_{\text {total }} & =\text { Emission }_{\mathrm{MD}, i}+0.5 \text { Emission }_{\mathrm{PA}, i-1} \\
& +0.25 \text { Emission }_{\mathrm{OH}, i-1}
\end{aligned}
$$

where the subscript $i$ represents the flight date, and $i-1$ represents upwind emissions from the day before (Table 1). The coefficients of 0.5 and 0.25 are used under a simple assumption based on the distance between the upwind sources and air pollutants over eastern MD, i.e., PA is next to MD so half of the CEMS emissions are assumed to be transported into $\mathrm{MD}$ while $\mathrm{OH}$ is farther away, so the coefficient is assumed to be 0.25 . Values of the coefficients used for other clusters are given in Table 1. Our analysis is insensitive to the exact value of these coefficients, as discussed below.

Figure 13 shows a scatter plot of CEMS emissions found using coefficients given in Table 1 versus measured column ozone between the surface and $1500 \mathrm{~m}$ AGL. Linear regression analyses were conducted for each cluster ( $r$ values are listed in Table 1), and only the OH/PA cluster shows a strong correlation between upwind emissions and downwind air pollution. We also correlated ozone column abundances with emission estimates assuming double (high estimate) and half (low estimate) of these coefficients in Table 1 (see Fig. S9 in the Supplement). Ozone over the Harford County airport shows a strong positive correlation with emissions from the $\mathrm{OH} / \mathrm{PA}$ cluster with little sensitivity to the exact value of these coefficients. However, the correlation between column ozone and MD emissions is low (Fig. S10 in the Supplement), suggesting that emissions from MD alone are a poor predictor of ozone pollution within this state. In summary, emissions of $\mathrm{NO}_{\mathrm{x}}$ in $\mathrm{OH}$ and PA substantially influence the ground-level air quality in the Baltimore/Washington area during the ozone season. Interstate/regional transport should be taken into account in plans to improve future air quality in the Baltimore/Washington area.

\section{Conclusions and discussion}

We have investigated the long-term trends of air pollution in the lower troposphere in the Baltimore/Washington airshed through a comprehensive study using emissions, aircraft, ground-based, and satellite measurements, as well as a clustering back trajectory analysis.

The EPA CEMS program continuously monitors emissions of $\mathrm{NO}_{\mathrm{x}}$ from major point sources including power plants and industrial boilers. Emissions data and atmospheric observations were used to investigate the regional transport of air pollutants. The long-term trends of CEMS data emissions demonstrate a significant decrease in the emission of 


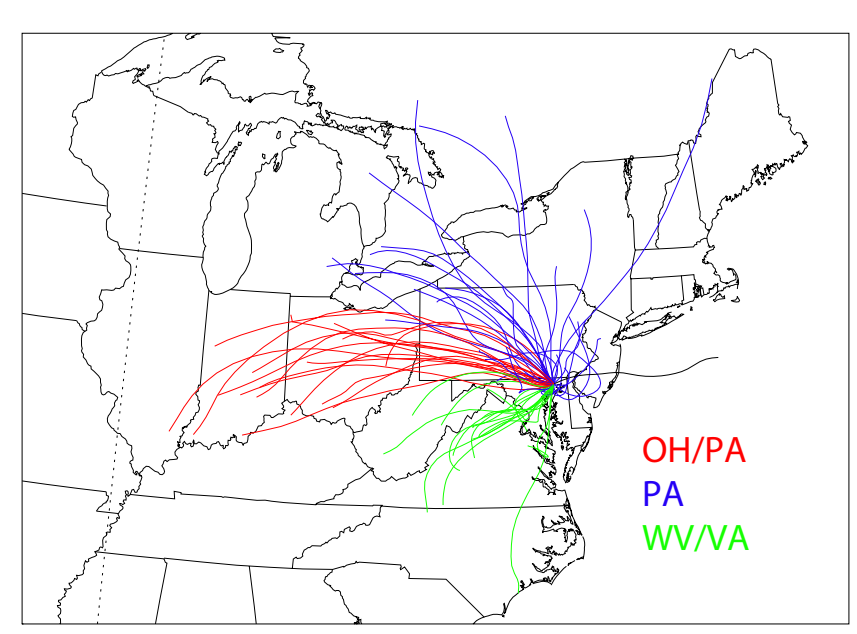

Fig. 12. Clustering results of HYSPLIT back trajectories (initiated at $1000 \mathrm{~m}$ ) from historical RAMMPP research flights over Harford County airport. The air parcels have origins from the west $(\mathrm{OH} / \mathrm{PA}$ cluster shown in red), the northwest (PA cluster shown in blue), or the southwest (WV/VA cluster shown in green). The black line shows a single trajectory for a flight conducted on 3 September 2009 called a background flight, with air flow from the east.

$\mathrm{NO}_{\mathrm{x}}$ over the past $15 \mathrm{yr}$. The EPA NO $\mathrm{x}$ SIP call (2003-2004) has been effective in reducing the emission of $\mathrm{NO}_{\mathrm{x}}$ from point sources, which improved local and regional air quality, especially ground-level ozone. The EPA AQS $\mathrm{NO}_{\mathrm{x}}$ observations declined by an amount similar to that of the CEMS emissions, with both time series exhibiting a sharp decrease after the EPA $\mathrm{NO}_{\mathrm{x}}$ SIP call.

The aircraft measurements of $\mathrm{O}_{3}$ and its precursor $\mathrm{CO}$ were integrated to obtain column abundances, and categorized into upwind and downwind groups. The difference of tropospheric column ozone between the downwind and upwind group was used to estimate the daily net photochemical production of ambient ozone: $\sim 3.0 \mathrm{DU} \mathrm{day}^{-1}$ in the late 1990 s and $\sim 1.0$ DU day $^{-1}$ in the early 2010 s, equivalent to $\sim 20 \mathrm{ppbv}^{-1 a y^{-1}}$ and $\sim 7 \mathrm{ppbv}$ day $^{-1}$ averaged over the lowest $1500 \mathrm{~m}$ of the atmosphere. The decreasing trends of $\mathrm{CO}$ and $\mathrm{O}_{3}$ were found to be $\sim 0.8$ and $\sim 0.2 \mathrm{DU} \mathrm{yr}^{-1}$, respectively, equivalent to decreases of $\sim 35$ and $\sim 1.3$ ppbv yr $^{-1}$ in the lowest $1500 \mathrm{~m}$. Because RAMMPP research flights are mostly conducted on air quality action days, the measurements indicate ozone pollution has significantly improved on days when the local meteorological conditions have historically been associated with poor air quality. Groundbased observations, RAMMPP aircraft measurements, and MOPITT spaced-based observations of CO show a $\sim 40 \%$ $\left(\sim 3.5 \% \mathrm{yr}^{-1}\right)$ decrease over western MD between 2000 and 2011 , while the NEI emissions inventory suggests a $\sim 60 \%$ $\left(\sim 4.5 \% \mathrm{yr}^{-1}\right)$ reduction over this same period of time.

To investigate the effects of long-range transport of air pollutants, in particular from power plants with high smokestacks, back trajectories were calculated using the
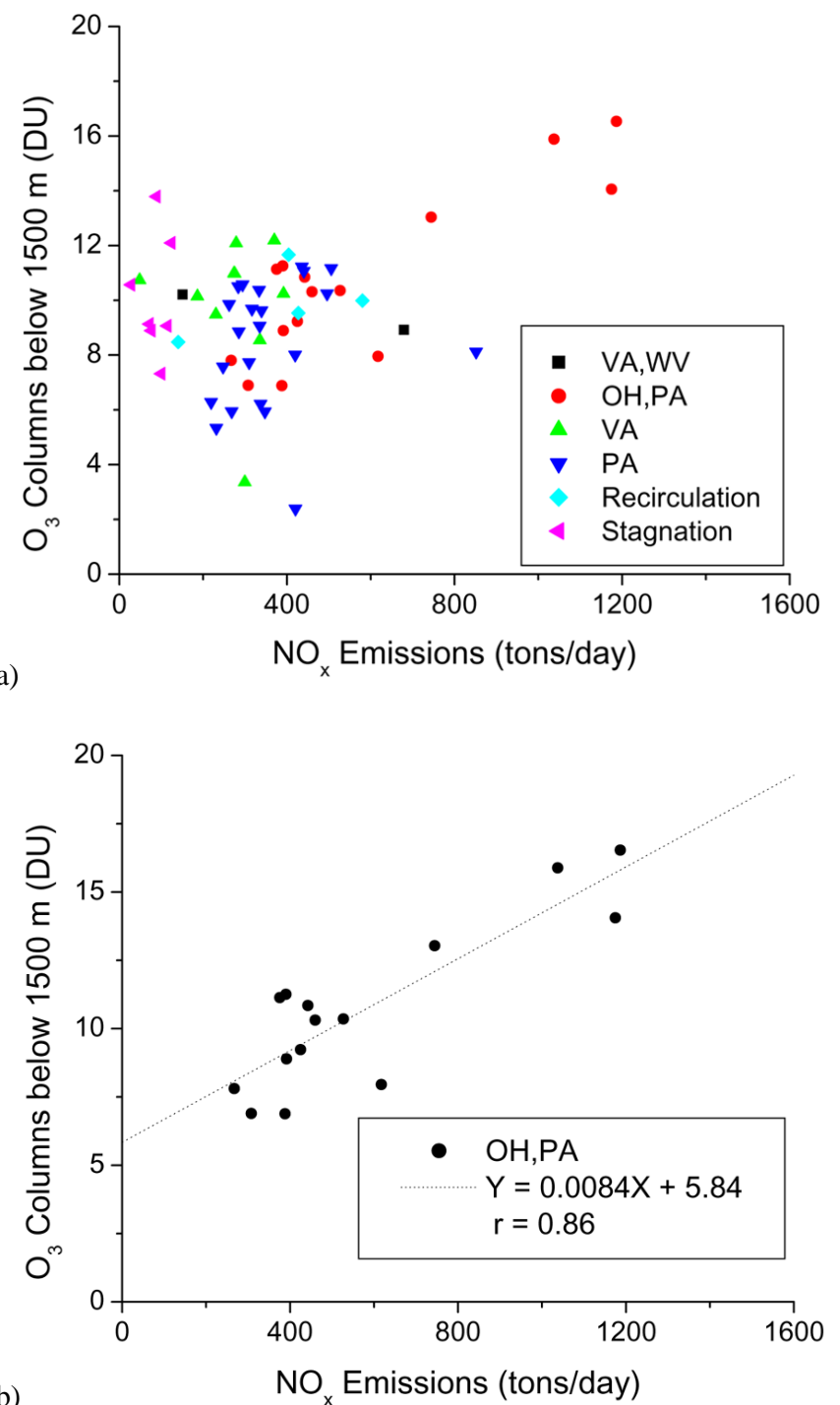

(b)

Fig. 13. $\mathrm{RAMMPP}$ column $\mathrm{O}_{3}$ abundance versus CEMS emissions of $\mathrm{NO}_{\mathrm{x}}$ : (a) all clusters; (b) OH/PA cluster only for which linear regression of column $\mathrm{O}_{3}$ vs. CEMS emissions of $\mathrm{NO}_{\mathrm{x}}$ was conducted (slope, intercept, and regression coefficient given).

NOAA HYSPLIT model. These trajectories fell into several clusters, and total $\mathrm{NO}_{\mathrm{x}}$ emissions were estimated for the geographic origins corresponding to each cluster. We performed a linear regression analysis for each cluster, and found that transport from $\mathrm{OH}$ and $\mathrm{PA}$ through MD has greatest effect on column abundances of ozone in the Baltimore/Washington airshed. Ozone over eastern MD correlates strongly $(r=$ $0.86)$ with emissions of $\mathrm{NO}_{\mathrm{x}}$ from upwind states such as $\mathrm{OH}$ and $\mathrm{PA}$, when the trajectory analysis indicated westerly transport. The next highest correlation is with a recirculation pattern involving MD, VA, and PA $(r=0.53)$.

According to the NEI inventory, $\sim 90 \%$ of $\mathrm{CO}$ and $\sim 50 \%$ $\mathrm{NO}_{\mathrm{x}}$, important precursors for ozone pollution, are emitted by mobile sources (onroad and nonroad vehicles). In this 
study, annual mobile emissions from the EPA NEI inventory were used to track the long-term trend in air quality, because seasonal and diurnal variations of mobile emissions are not directly available. However, the seasonal and diurnal variations of mobile emissions could be important, so future work on quantifying these variations is essential to refine our understanding of the effects of regional and local emissions of ozone precursors on air quality

Overall, this study reveals that recent regulation of emissions of ozone precursors substantially improved the air quality of the Baltimore/Washington airshed. We also find that the regional transport of $\mathrm{NO}_{\mathrm{x}}$ from point sources in upwind $\mathrm{PA}$ and $\mathrm{OH}$ still exert considerable influence on the downwind ozone pollution of the Baltimore/Washington area. These results identify the effects of emission controls on local air quality under complex regional transport patterns, which can inform future air quality planning and emission regulations in the eastern US.

\section{Supplementary material related to this article is available online at: http://www.atmos-chem-phys.net/13/ 7859/2013/acp-13-7859-2013-supplement.pdf.}

Acknowledgements. We thank Maryland Department of the Environment for supporting the RAMMPP program for the past decades. We thank Juying Warner (University of Maryland, College Park) for helpful comments. Canty, Hosley, and Salawitch appreciate support from the National Aeronautics and Space Administration (NASA) for their participation in this research effort. We thank Roland Draxler and Fong Ngan (National Oceanic and Atmospheric Administration) for help on the HYSPLIT model. The National Center for Atmospheric Research (NCAR) is sponsored by the National Science Foundation. The NCAR MOPITT project is supported by the NASA Earth Observing System (EOS) program. The support of the NASA AURA Science Team and the Air Quality Applied Science Team (AQAST) is gratefully acknowledged. We thank the two anonymous reviewers for their helpful comments.

Edited by: B. N. Duncan

\section{References}

Adams, R. M., Glyer, J. D., Johnson, S. L., and McCarl, B. A.: A reassessment of the economic-effects of ozone on United States agriculture, Japca, 39, 960-968, 1989.

Anderson, H. R.: Air pollution and mortality: A history, Atmos. Environ., 43, 142-152, doi:10.1016/j.atmosenv.2008.09.026, 2009.

Ashmore, M. R.: Assessing the future global impacts of ozone on vegetation, Plant Cell Environ., 28, 949-964, doi:10.1111/j.1365-3040.2005.01341.x, 2005.

Bloomer, B. J., Stehr, J. W., Piety, C. A., Salawitch, R. J., and Dickerson, R. R.: Observed relationships of ozone air pollution with temperature and emissions, Geophys. Res. Lett., 36, 5, L09803, doi:10.1029/2009g1037308, 2009.

Bloomer, B. J., Vinnikov, K. Y., and Dickerson, R. R.: Changes in seasonal and diurnal cycles of ozone and temperature in the eastern us, Atmos. Environ., 44, 2543-2551, doi:10.1016/j.atmosenv.2010.04.031, 2010.

Bromba, M. U. A. and Ziegler, H.: Application hints for SavitzkyGolay digital smoothing filters, Anal. Chem., 53, 1583-1586, doi:10.1021/ac00234a011, 1981.

Butler, T. J., Vermeylen, F. M., Rury, M., Likens, G. E., Lee, B., Bowker, G. E., and McCluney, L.: Response of ozone and nitrate to stationary source $\mathrm{NO}_{\mathrm{x}}$ emission reductions in the eastern USA, Atmos. Environ., 45, 1084-1094, doi:10.1016/j.atmosenv.2010.11.040, 2011.

Camalier, L., Cox, W., and Dolwick, P.: The effects of meteorology on ozone in urban areas and their use in assessing ozone trends, Atmos. Environ., 41, 7127-7137, doi:10.1016/j.atmosenv.2007.04.061, 2007.

Castellanos, P., Marufu, L. T., Doddridge, B. G., Taubman, B. F., Schwab, J. J., Hains, J. C., Ehrman, S. H., and Dickerson, R. R.: Ozone, oxides of nitrogen, and carbon monoxide during pollution events over the eastern united states: An evaluation of emissions and vertical mixing, J. Geophys. Res.-Atmos., 116, 16, D16307, doi:10.1029/2010jd014540, 2011.

Chameides, W. L., Li, X. S., Tang, X. Y., Zhou, X. J., Luo, C., Kiang, C. S., St John, J., Saylor, R. D., Liu, S. C., Lam, K. S., Wang, T., and Giorgi, F.: Is ozone pollution affecting crop yields in china?, Geophys. Res. Lett., 26, 867-870, doi:10.1029/1999g1900068, 1999.

Chan, E. and Vet, R. J.: Baseline levels and trends of ground level ozone in Canada and the United States, Atmos. Chem. Phys., 10, 8629-8647, doi:10.5194/acp-10-8629-2010, 2010.

Cooper, O. R., Parrish, D. D., Stohl, A., Trainer, M., Nedelec, P., Thouret, V., Cammas, J. P., Oltmans, S. J., Johnson, B. J., Tarasick, D., Leblanc, T., McDermid, I. S., Jaffe, D., Gao, R., Stith, J., Ryerson, T., Aikin, K., Campos, T., Weinheimer, A., and Avery, M. A.: Increasing springtime ozone mixing ratios in the free troposphere over western north America, Nature, 463, 344-348, doi:10.1038/nature08708, 2010.

Cooper, O. R., Gao, R. S., Tarasick, D., Leblanc, T., and Sweeney, C.: Long-term ozone trends at rural ozone monitoring sites across the United States, 1990-2010, J. Geophys. Res.-Atmos., 117, D22307, doi:10.1029/2012jd018261, 2012.

Corsmeier, U., Kalthoff, N., Kolle, O., Kotzian, M., and Fiedler, F.: Ozone concentration jump in the stable nocturnal boundary layer during a LLJ-event, Atmos. Environ., 31, 1977-1989, doi:10.1016/s1352-2310(96)00358-5, 1997.

Crutzen, P. J.: Photochemical reactions initiated by and influencing ozone in unpolluted tropospheric air, Tellus, 26, 47-57, 1974.

Deeter, M. N., Emmons, L. K., Francis, G. L., Edwards, D. P., Gille, J. C., Warner, J. X., Khattatov, B., Ziskin, D., Lamarque, J. F., Ho, S. P., Yudin, V., Attie, J. L., Packman, D., Chen, J., Mao, D., and Drummond, J. R.: Operational carbon monoxide retrieval algorithm and selected results for the MOPPIT instrument, J. Geophys. Res.-Atmos., 108, 4399, doi:10.1029/2002jd003186, 2003.

Deeter, M. N., Worden, H. M., Edwards, D. P., Gille, J. C., and Andrews, A. E.: Evaluation of MOPITT retrievals of lowertropospheric carbon monoxide over the United States, J. Geophys. Res.-Atmos., 117, D13306, doi:10.1029/2012jd017553, 
2012.

Dickerson, R. R. and Delany, A. C.: Modification of a commercial gas filter correlation co detector for enhanced sensitivity, J. Atmos. Oc. Technol., 5, 424-4-31, 1988.

Dunlea, E. J., Herndon, S. C., Nelson, D. D., Volkamer, R. M., San Martini, F., Sheehy, P. M., Zahniser, M. S., Shorter, J. H., Wormhoudt, J. C., Lamb, B. K., Allwine, E. J., Gaffney, J. S., Marley, N. A., Grutter, M., Marquez, C., Blanco, S., Cardenas, B., Retama, A., Ramos Villegas, C. R., Kolb, C. E., Molina, L. T., and Molina, M. J.: Evaluation of nitrogen dioxide chemiluminescence monitors in a polluted urban environment, Atmos. Chem. Phys., 7, 2691-2704, doi:10.5194/acp-7-2691-2007, 2007.

EPA: Air quality criteria for ozone and related photochemical oxidants. Report Nos. EPA/600/r-05/004sf, office of research and development, Research Triangle Park, NC, February 2006. US Environmental Protection Agency, 2006.

EPA: The $\mathrm{NO}_{\mathrm{x}}$ budget trading program: 2008 environmental results, Washington, DC, available at: http://www.epa.gov/airmarkets/ progress/NBP_3/NBP_2008_Environmental_Results.pdf, 2009.

EPA: Mid-Atlantic air quality, http://www.epa.gov/reg3artd/ airquality/airquality.htm, 2012a.

EPA: Federal register notices related to 8-hour ozone designations and classifications, http://www.epa.gov/oar/oaqps/greenbk/ gfrnrpt4.Html, 2012b.

Fehsenfeld, F. C., Dickerson, R. R., Hübler, G., Luke, W. T., Nunnermacker, L. J., Williams, E. J., Roberts, J. M., Calvert, J. G., Curran, C. M., Delany, A. C., Eubank, C. S., Fahey, D. W., Fried, A., Gandrud, B. W., Langford, A. O., Murphy, P. C., Norton, R. B., Pickering, K. E., and Ridley, B. A.: A ground-based intercomparison of $\mathrm{NO}, \mathrm{NO}_{\mathrm{x}}$, and $\mathrm{NO}_{y}$ measurement techniques, J. Geophys. Res.-Atmos., 92, 14710-14722, doi:10.1029/JD092iD12p14710, 1987.

Fiore, A. M., Jacob, D. J., Logan, J. A., and Yin, J. H.: Longterm trends in ground level ozone over the contiguous United States, 1980-1995, J. Geophys. Res.-Atmos., 103, 1471-1480, doi:10.1029/97jd03036, 1998.

Fishman, J., Ramanathan, V., Crutzen, P. J., and Liu, S. C.: Tropospheric ozone and climate, Nature, 282, 818-820, doi:10.1038/282818a0, 1979a.

Fishman, J., Solomon, S., and Crutzen, P. J.: Observational and theoretical evidence in support of a significant in situ photochemical source of tropospheric ozone, Tellus, 31, 432-446, 1979b.

Frost, G. J., McKeen, S. A., Trainer, M., Ryerson, T. B., Neuman, J. A., Roberts, J. M., Swanson, A., Holloway, J. S., Sueper, D. T., Fortin, T., Parrish, D. D., Fehsenfeld, F. C., Flocke, F., Peckham, S. E., Grell, G. A., Kowal, D., Cartwright, J., Auerbach, N., and Habermann, T.: Effects of changing power plant $\mathrm{NO}_{\mathrm{x}}$ emissions on ozone in the eastern United States: Proof of concept, J. Geophys. Res.-Atmos., 111, D12306, doi:10.1029/2005jd006354, 2006.

GAO: Information on tall smokestacks and their contribution to interstate transport of air pollution, United States Government Accountability Office (GAO), Washington DC, 2011.

Gorry, P. A.: General least-squares smoothing and differentiation by the convolution (Savitzky-Golay) method, Anal. Chem., 62, 570-573, doi:10.1021/ac00205a007, 1990.

Haagensmit, A. J.: Chemistry and physiology of LosAngeles smog, Industr. Engin. Chem., 44, 1342-1346, doi:10.1021/ie50510a045, 1952.

Haagensmit, A. J. and Fox, M. M.: Ozone formation in photochemical oxidation of organic substances, Industr. Engin. Chem., 48, 1484-1487, doi:10.1021/ie51400a033, 1956.

Hains, J. C., Taubman, B. F., Thompson, A. M., Stehr, J. W., Marufu, L. T., Doddridge, B. G., and Dickerson, R. R.: Origins of chemical pollution derived from Mid-Atlantic aircraft profiles using a clustering technique, Atmos. Environ., 42, 1727-1741, doi:10.1016/j.atmosenv.2007.11.052, 2008.

Hallock-Waters, K. A., Doddridge, B. G., Dickerson, R. R., Spitzer, S., and Ray, J. D.: Carbon monoxide in the US Mid-Atlantic troposphere: Evidence for a decreasing trend, Geophys. Res. Lett., 26, 2861-2864, doi:10.1029/1999g1900609, 1999.

Higgins, R. W., Yao, Y., Yarosh, E. S., Janowiak, J. E., and Mo, K. C.: Influence of the great plains low-level jet on summertime precipitation and moisture transport over the central united states, J. Climate, 10, 481-507, doi:10.1175/15200442(1997)010<0481:iotgpl>2.0.co;2, 1997.

Holton, J. R., Haynes, P. H., McIntyre, M. E., Douglass, A. R., Rood, R. B., and Pfister, L.: Stratosphere-troposphere exchange, Rev. Geophys., 33, 403-439, doi:10.1029/95rg02097, 1995.

IPCC: Climate change 2007: The physical science basis, Contribution of Working Group I to the Fourth Assessment Report (AR4) of the Intergovernmental Panel on Climate Change, 996 pp., 2007.

Jacob, D. J. and Winner, D. A.: Effect of climate change on air quality, Atmos. Environ., 43, 51-63, doi:10.1016/j.atmosenv.2008.09.051, 2009.

Jaffe, D.: Relationship between surface and free tropospheric ozone in the western US, Environ. Sci. Technol., 45, 432-438, doi:10.1021/es1028102, 2011.

Jaffe, D. and Ray, J.: Increase in surface ozone at rural sites in the western US, Atmos. Environ., 41, 5452-5463, doi:10.1016/j.atmosenv.2007.02.034, 2007.

Jerrett, M., Burnett, R. T., Pope, C. A., Ito, K., Thurston, G., Krewski, D., Shi, Y. L., Calle, E., and Thun, M.: Long-term ozone exposure and mortality, N. Engl. J. Med., 360, 1085-1095, doi:10.1056/NEJMoa0803894, 2009.

Kesselmeier, J. and Staudt, M.: Biogenic volatile organic compounds (VOC): An overview on emission, physiology and ecology, Journal of Atmospheric Chemistry, 33, 23-88, doi:10.1023/a:1006127516791, 1999.

Kim, S. W., Heckel, A., McKeen, S. A., Frost, G. J., Hsie, E. Y., Trainer, M. K., Richter, A., Burrows, J. P., Peckham, S. E., and Grell, G. A.: Satellite-observed us power plant $\mathrm{NO}_{\mathrm{x}}$ emission reductions and their impact on air quality, Geophys. Res. Lett., 33, L22812, doi:10.1029/2006g1027749, 2006.

Lefohn, A. S., Shadwick, D., and Oltmans, S. J.: Characterizing long-term changes in surface ozone levels in the United States (1980-2005), Atmos. Environ., 42, 8252-8262, doi:10.1016/j.atmosenv.2008.07.060, 2008.

Lefohn, A. S., Shadwick, D., and Oltmans, S. J.: Characterizing changes in surface ozone levels in metropolitan and rural areas in the United States for 1980-2008 and 1994-2008, Atmos. Environ., 44, 5199-5210, doi:10.1016/j.atmosenv.2010.08.049, 2010.

Levy, H.: Normal atmosphere: large radical and formaldehyde concentrations predicted, Science, 173, 141-143, doi:10.1126/science.173.3992.141, 1971. 
Levy, H., Mahlman, J. D., Moxim, W. J., and Liu, S. C.: Tropospheric ozone - the role of transport, J. Geophys. Res.-Atmos., 90, 3753-3772, doi:10.1029/JD090iD02p03753, 1985.

Lin, M. Y., Fiore, A. M., Horowitz, L. W., Cooper, O. R., Naik, V., Holloway, J., Johnson, B. J., Middlebrook, A. M., Oltmans, S. J., Pollack, I. B., Ryerson, T. B., Warner, J. X., Wiedinmyer, C., Wilson, J., and Wyman, B.: Transport of Asian ozone pollution into surface air over the western United States in spring, J. Geophys. Res.-Atmos., 117, D00v07, doi:10.1029/2011jd016961, 2012.

Logan, J. A., Prather, M. J., Wofsy, S. C., and McElroy, M. B.: Tropospheric chemistry: a global perspective, J. Geophys. Res.-Oc. Atmos., 86, 7210-7254, doi:10.1029/JC086iC08p07210, 1981.

Loughner, C. P., Allen, D. J., Pickering, K. E., Zhang, D. L., Shou, Y. X., and Dickerson, R. R.: Impact of fair-weather cumulus clouds and the Chesapeake bay breeze on pollutant transport and transformation, Atmos. Environ., 45, 4060-4072, doi:10.1016/j.atmosenv.2011.04.003, 2011.

Luke, W. T., Dickerson, R. R., Ryan, W. F., Pickering, K. E., and Nunnermacker, L. J.: Tropospheric chemistry over the lower Great Plains of the United States 2, trace gas profiles and distributions, J. Geophys. Res.-Atmos., 97, 20647-20670, 1992.

Martins, D. K., Stauffer, R. M., Thompson, A. M., Halliday, H. S., Kollonige, D. W., Joseph, E., and Weinheimer, A. J.: Ozone correlations between upper air partial columns and the near-surface at two Mid-Atlantic sites during the DISCOVER-AQ campaign in July 2011, J. Atmos. Chem., in press, doi:10.1007/s10874013-9259-4, 2013.

Marufu, L. T., Taubman, B. F., Bloomer, B., Piety, C. A., Doddridge, B. G., Stehr, J. W., and Dickerson, R. R.: The 2003 North American electrical blackout: An accidental experiment in atmospheric chemistry, Geophys. Res. Lett., 31, L13106, doi:10.1029/2004g1019771, 2004.

Neuman, J. A., Trainer, M., Aikin, K. C., Angevine, W. M., Brioude, J., Brown, S. S., de Gouw, J. A., Dube, W. P., Flynn, J. H., Graus, M., Holloway, J. S., Lefer, B. L., Nedelec, P., Nowak, J. B., Parrish, D. D., Pollack, I. B., Roberts, J. M., Ryerson, T. B., Smit, H., Thouret, V., and Wagner, N. L.: Observations of ozone transport from the free troposphere to the Los Angeles basin, J. Geophys. Res.-Atmos., 117, 15, D00v09, doi:10.1029/2011jd016919, 2012.

Oltmans, S. J., Lefohn, A. S., Harris, J. M., Galbally, I., Scheel, H. E., Bodeker, G., Brunke, E., Claude, H., Tarasick, D., Johnson, B. J., Simmonds, P., Shadwick, D., Anlauf, K., Hayden, K., Schmidlin, F., Fujimoto, T., Akagi, K., Meyer, C., Nichol, S., Davies, J., Redondas, A., and Cuevas, E.: Long-term changes in tropospheric ozone, Atmos. Environ., 40, 3156-3173, doi:10.1016/j.atmosenv.2006.01.029, 2006.

Oltmans, S. J., Lefohn, A. S., Harris, J. M., and Shadwick, D. S.: Background ozone levels of air entering the west coast of the US and assessment of longer-term changes, Atmos. Environ., 42, 6020-6038, doi:10.1016/j.atmosenv.2008.03.034, 2008.

Oltmans, S. J., Lefohn, A. S., Shadwick, D., Harris, J. M., Scheel, H. E., Galbally, I., Tarasick, D. W., Johnson, B. J., Brunke, E. G., Claude, H., Zeng, G., Nichol, S., Schmidlin, F., Davies, J., Cuevas, E., Redondas, A., Naoe, H., Nakano, T., and Kawasato, T.: Recent tropospheric ozone changes: a pattern dominated by slow or no growth, Atmos. Environ., 67, 331-351, doi:10.1016/j.atmosenv.2012.10.057, 2013.
Parrish, D. D., Millet, D. B., and Goldstein, A. H.: Increasing ozone in marine boundary layer inflow at the west coasts of North America and Europe, Atmos. Chem. Phys., 9, 1303-1323, doi:10.5194/acp-9-1303-2009, 2009.

Ramanathan, V. and Dickinson, R. E.: Role of stratospheric ozone in the zonal and seasonal radiative energy-balance of the earthtroposphere system, J. Atmos. Sci., 36, 1084-1104, 1979.

Savitzky, A. and Golay, M. J. E.: Smoothing + differentiation of data by simplified least squares procedures, Anal. Chem., 36, 1627-1639, doi:10.1021/ac60214a047, 1964.

Schwab, J. J., Spicer, J. B., and Demerjian, K. L.: Ozone, trace gas, and particulate matter measurements at a rural site in southwestern New York state: 1995-2005, J. Air Waste Manage. Assoc., 59, 293-309, doi:10.3155/1047-3289.59.3.293, 2009.

Seinfeld, J. H. and Pandis, S. N.: Atmospheric chemistry and physics: From air pollution to climate change, 2nd Edn., John Wiley \& Sons, Inc., 2006.

Stauffer, R. M., Thompson, A. M., Martins, D. K., Clark, R. D., Goldberg, D. L., Loughner, C. P., Delgado, R., Dickerson, R. R., Stehr, J. W., and Tzortziou, M. A.: Bay breeze influence on surface ozone at Edgewood, MD during July 2011, J. Atmos. Chem., 1-19, doi:10.1007/s10874-012-9241-6, 2013.

Stevenson, D. S., Dentener, F. J., Schultz, M. G., Ellingsen, K., van Noije, T. P. C., Wild, O., Zeng, G., Amann, M., Atherton, C. S., Bell, N., Bergmann, D. J., Bey, I., Butler, T., Cofala, J., Collins, W. J., Derwent, R. G., Doherty, R. M., Drevet, J., Eskes, H. J., Fiore, A. M., Gauss, M., Hauglustaine, D. A., Horowitz, L. W., Isaksen, I. S. A., Krol, M. C., Lamarque, J. F., Lawrence, M. G., Montanaro, V., Muller, J. F., Pitari, G., Prather, M. J., Pyle, J. A., Rast, S., Rodriguez, J. M., Sanderson, M. G., Savage, N. H., Shindell, D. T., Strahan, S. E., Sudo, K., and Szopa, S.: Multimodel ensemble simulations of present-day and near-future tropospheric ozone, J. Geophys. Res.-Atmos., 111, D08301, doi:10.1029/2005jd006338, 2006.

Stohl, A.: Computation, accuracy and applications of trajectories: a review and bibliography, Atmos. Environ., 32, 947-966, doi:10.1016/s1352-2310(97)00457-3, 1998.

Stohl, A., Wotawa, G., Seibert, P., and Krompkolb, H.: Interpolation errors in wind fields as a function of spatial and temporal resolution and their impact on different types of kinematic trajectories, Journal of Applied Meteorology, 34, 2149-2165, doi:10.1175/1520-0450(1995)034<2149:ieiwfa > 2.0.co;2, 1995.

Stohl, A., Eckhardt, S., Forster, C., James, P., Spichtinger, N., and Seibert, P.: A replacement for simple back trajectory calculations in the interpretation of atmospheric trace substance measurements, Atmos. Environ., 36, 4635-4648, doi:10.1016/s13522310(02)00416-8, 2002.

Stohl, A., Forster, C., Eckhardt, S., Spichtinger, N., Huntrieser, H., Heland, J., Schlager, H., Wilhelm, S., Arnold, F., and Cooper, O.: A backward modeling study of intercontinental pollution transport using aircraft measurements, J. Geophys. Res.-Atmos., 108, 4370, doi:10.1029/2002jd002862, 2003.

Stunder, B. J. B.: An assessment of the quality of forecast trajectories, Journal of Applied Meteorology, 35, 1319-1331, doi:10.1175/1520-0450(1996)035<1319:aaotqo > 2.0.co;2, 1996.

Taubman, B. F., Hains, J. C., Thompson, A. M., Marufu, L. T., Doddridge, B. G., Stehr, J. W., Piety, C. A., and Dickerson, R. 
R.: Aircraft vertical profiles of trace gas and aerosol pollution over the Mid-Atlantic United States: Statistics and meteorological cluster analysis, J. Geophys. Res.-Atmos., 111, 14, D10s07, doi:10.1029/2005jd006196, 2006.

WHO: Health aspects of air pollution with particulate matter, ozone and nitrogen dioxide, World Health Organization, Bonn,, 2003.

Wild, O., Sundet, J. K., Prather, M. J., Isaksen, I. S. A., Akimoto, H., Browell, E. V., and Oltmans, S. J.: Chemical transport model ozone simulations for spring 2001 over the western pacific: Comparisons with TRACE-P lidar, ozonesondes, and Total Ozone Mapping Spectrometer columns, J. Geophys. Res.-Atmos., 108, 8826, doi:10.1029/2002jd003283, 2003.

Worden, H. M., Deeter, M. N., Edwards, D. P., Gille, J. C., Drummond, J. R., and Nedelec, P.: Observations of nearsurface carbon monoxide from space using MOPITT multispectral retrievals, J. Geophys. Res.-Atmos., 115, D18314, doi:10.1029/2010jd014242, 2010.
Worden, H. M., Deeter, M. N., Frankenberg, C., George, M., Nichitiu, F., Worden, J., Aben, I., Bowman, K. W., Clerbaux, C., Coheur, P. F., de Laat, A. T. J., Detweiler, R., Drummond, J. R., Edwards, D. P., Gille, J. C., Hurtmans, D., Luo, M., MartinezAlonso, S., Massie, S., Pfister, G., and Warner, J. X.: Decadal record of satellite carbon monoxide observations, Atmos. Chem. Phys., 13, 837-850, doi:10.5194/acp-13-837-2013, 2013.

Yorks, J. E., Thompson, A. M., Joseph, E., and Miller, S. K.: The variability of free tropospheric ozone over Beltsville, Maryland $\left(39^{\circ} \mathrm{N}, 77^{\circ} \mathrm{W}\right)$ in the summers 2004-2007, Atmos. Environ., 43, 1827-1838, doi:10.1016/j.atmosenv.2008.12.049, 2009. 